\title{
PLACE - AN INTRODUCTION
}

\section{Tim Cresswell: Place - an introduction. Chichester, Wiley Blackwell, 2015, 220 str.}

Prevajanje strokovnih izrazov iz tujih jezikov v slovenščino in njihova uporaba sta za marsikaterega geografa precejšen izziv: nemalokrat je težko najti slovensko besedo, ki bi pomensko povsem ustrezala pojmu v tujem jeziku, ki ga želimo prevesti. Angleški pojem place je le eden od primerov, o katerem so mnenja o slovenski ustreznici izrazito pestra in neenotna (place se neenotno prevaja z izrazi kraj, območje, ozemlje). V tem prispevku je zato pojem place ostal nepreveden, saj sovpada $\mathrm{z}$ naslovom pričujoče knjige. Kakršenkoli poizkus prevajanja v slovenščino bi namreč moral biti obravnavan $\mathrm{v}$ ločenem prispevku, podkrepljenem $\mathrm{z}$ referencami iz znanstvene literature $\mathrm{s}$ področja teorije geografije.

V knjigi Place je avtor, britanski geograf Tim Cresswell, pojem place v sedmih poglavjih podrobno osvetlil ter prikazal njegovo pomensko raznolikost in večplastnost. Uvodno poglavje je namenjeno problematiki opredeljevanja pojma place: na prvi pogled se ta beseda govorcem angleščine zdi preprosta in prikladna za uporabo $\mathrm{v}$ vsakodnevnem pogovoru, vendar pa avtor prikaže njeno nedorečenost in pomensko spremenljivost, zaradi katerih so se raziskovalci uporabi tega pojma dolgo izogibali in ga $\mathrm{v}$ raziskavah niso uporabljali. To ugotovitev avtor nadgradi tudi v drugem poglavju o izvoru in razvoju pojma place vse od antičnih in srednjeveških mislecev do sodobnih filozofov in geografov, ki so vplivali na sodobno razmišljanje o prostoru (npr. Martin Heidegger, Henri Lefebvre, Yi-Fu Tuan).

Aktualna teoretska izhodišča s pojmom place pogosto označujejo posameznikov »življenjski prostor «, v katerem bolj ali manj ustaljeno živi in je nanj čustveno navezan. S tega zornega kota je pojem place pomensko soroden pojmu »dom«, le da je pomensko nekoliko širši. V tretjem poglavju avtor pojem place sooči z rastočo mobilnostjo ljudi, kapitala in informacij. Kako se pod vplivom vse večje mobilnosti spreminja pogled na temeljne pojme humane geografije, kot so dom, narod, bivanje, država, naselje? Avtor izpostavi dejstvo, da je place nekaj, kar je tipično za človeka kot misleče bitje, ki bolj ali manj miselno "predela« območje, kjer živi in se nanj tudi naveže.

$\mathrm{V}$ četrtem poglavju avtor opozori, da je pojem place pogosto zlorabljen s strani populističnih političnih strank in nasprotnikov globalizacije, ki si prizadevajo za ohranitev lokalnih posebnosti in medkulturnih razlik. Peto poglavje je namenjeno obravnavi bolj ali manj načrtnega oblikovanja oziroma »izdelovanja « pojma place (t. i. place making, ki označuje človekovo prizadevanje za oblikovanje določenih območij po lastnih idejah in predstavah). Avtor opozori, da je ta proces neločljivo povezan s socialnimi skupinami, ki živijo na določenem območju oziroma so $\mathrm{z}$ njim povezane. $\mathrm{V}$ povezavi s pojmom 
place making avtor v podpoglavjih podrobno prikaže vlogo umetnosti in umetnikov, arhitekture, upravnih institucij ter vpliva digitalnih prostorov.

$\mathrm{V}$ predzadnjem poglavju se pojem place obravnava $\mathrm{z}$ vidika nenapisanih pravil, družbenih norm, $\mathrm{z}$ vidika geografije spola, brezdomcev in (ne)zaželenosti živali, kot so domači ljubljenčki, potepuški psi in celo živali, ki jih v nekaterih državah v razvoju po mestih redijo celo za prehrano. Sklepno poglavje prinaša pregled relevantnih knjig, člankov, projektov in revij s tega področja.

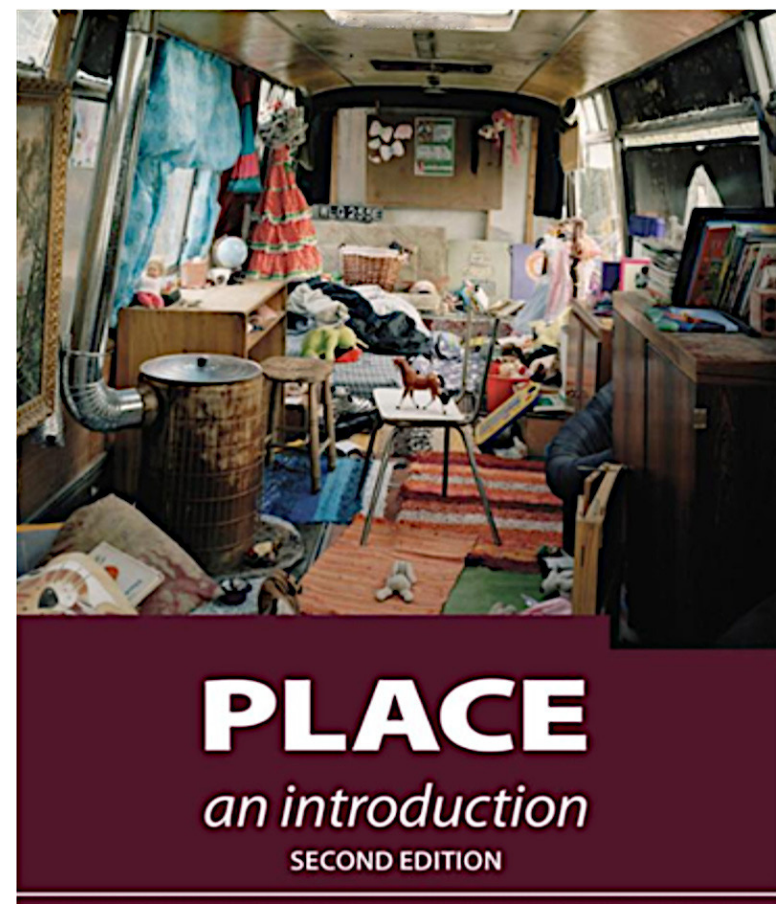

Tim Cresswell

WILEY Blackwell

Knjiga je z vidika strukture poglavij logično zgrajena. Od uvodne opredelitve in pregleda razvoja pojma place skozi zgodovino avtor $\mathrm{v}$ tretjem poglavju preide $\mathrm{k}$ večrazsežnostni obravnavi sodobnih razvojnih teženj pod vplivom naraščajoče mobilnosti ter spremenljivosti kapitala in informacij. Obravnava je nadgrajena tudi s pregledom človekove vsakdanje interakcije - "gradnje« oziroma "produkcije« pojma place.

Knjigo prevevata geografski način mišljenja in dosledna uporaba izrazja, ki je lastno geografiji kot znanstveni vedi. Na tej miselni podstati avtor razmišlja tudi o pojmu place. Pri proučevanju tega pojma pa se avtor ne omejuje zgolj na geografijo, 
ampak smiselno vključuje tudi stališča drugih znanstvenih ved, ki se ukvarjajo s tem pojmom: filozofije, sociologije, psihologije, pa tudi ontologije in epistemologije ter raznolikih zvrsti umetnosti (arhitektura, leposlovje in poezija).

$\mathrm{Z}$ navajanjem raznolikih pogledov več znanstvenih ved avtor nakazuje, da je o pojmu place nujen interdisciplinaren razmislek in zato ni možno preprosto oblikovati enotne opredelitve, ki bi pojem jasno zamejila in ga ločila od sorodnih pojmov, kot so pokrajina, prostor in lokacija (landscape, space, location). Po poglavju o opredelitvah in pregledu zgodovinskega razvoja pojma avtor argumentira, da je pojem place izrazito interdisciplinaren in ga je zato treba osvetliti s spoznanji različnih raziskovalcev.

Najpomembnejše misli in zapisi drugih avtorjev so ponekod v knjigi dobesedno navedene. Tudi zato avtorjev slog pisanja ni monoton, saj vključevanje navedkov in raznolikih grafičnih prilog besedilo popestri in vsebinsko nadgradi. Knjiga je pisana v jasnem in dokaj nezahtevnem jeziku.

Erik Logar

\title{
NEW MONEY IN RURAL AREAS. LAND INVESTMENT IN EUROPE AND ITS PLACE IMPACTS
}

\author{
Nick Gallent, lqbal Hamiduddin, Meri Juntti, Nicola Livingstone in Phoebe \\ Stirling: New money in rural areas. Land investment in Europe and its place \\ impacts. Singapore, Palgrave Macmillan, 2018, 166 str.
}

Prebivalci podeželja, usmerjevalci razvoja podeželja in njegovi raziskovalci pogosto soglašamo, da se na podeželje usmerja premalo investicij ter da jih večinoma vodita kratkoročna naravnanost in predvsem enostranski finančno-pridobitniški cilj vlagateljev. Znanstvena monografija $\mathrm{z}$ naslovom New money in rural areas. Land investment in Europe and its place impacts prinaša zanimive poglede na ključno vprašanje: kako bi bilo mogoče investicije usmerjati tako, da bi bila njihova dobrobit čim večja, negativni učinki na podeželju pa čim manjši?

Tako so se avtorji (Nick Gallent, Iqbal Hamiduddin, Meri Juntti, Nicola Livingstone in Phoebe Stirling, večinoma sodelavci Bartlett School of Planning, ki deluje v sklopu University College iz Londona) ukvarjali z investicijami v kmetijska zemljišča, ki so jih preučevali:

- $\mathrm{z}$ vidika neposredne (kmet kupi zemljišče, vlaga $\mathrm{v}$ opremo in stavbe; skladi kupijo gozdove in vinograde ipd.) in posredne investicije (vlaganje skladov in drugih ponudnikov finančnih storitev, ki se nimajo namena neposredno vključiti v pridelavo, predelavo itd., ampak jih zanimajo predvsem kapitalski donosi); 
- $\mathrm{z}$ vidika aktivnega (ki naredi nekaj, da se vrednost posesti in/ali zemljišč poveča) in pasivnega investitorja (običajno nima specializiranega znanja, večinoma kupi zemljišče kot varno naložbo ali kot del svoje širše investicijske strategije).

Dvoje izhodišč so avtorji povezali z različnimi vrstami investitorjev, in sicer z: investitorji-lastniki (kmetje, drugi zasebni vlagatelji, skladi, družinska podjetja, razvojne banke) in institucionalnimi investitorji (pokojninski skladi, javna podjetja, nepremičninski skladi, skladi hedge, zasebne naložbe - private equity). Veliko pozornosti je v monografiji namenjene tudi raziskavi dejavnikov, ki vplivajo na investicije na podeželju, pri čemer so avtorji prepoznali: (1) strukturno-tržne dejavnike (dolgoročna vrednost kmetijskih zemljišč, dohodek iz kmetijske proizvodnje), (2) strukturno-regulatorne dejavnike (davčna obravnava lastnikov zemljišč, finančna politika in podporne sheme) in (3) osebno motivacijo investitorja.

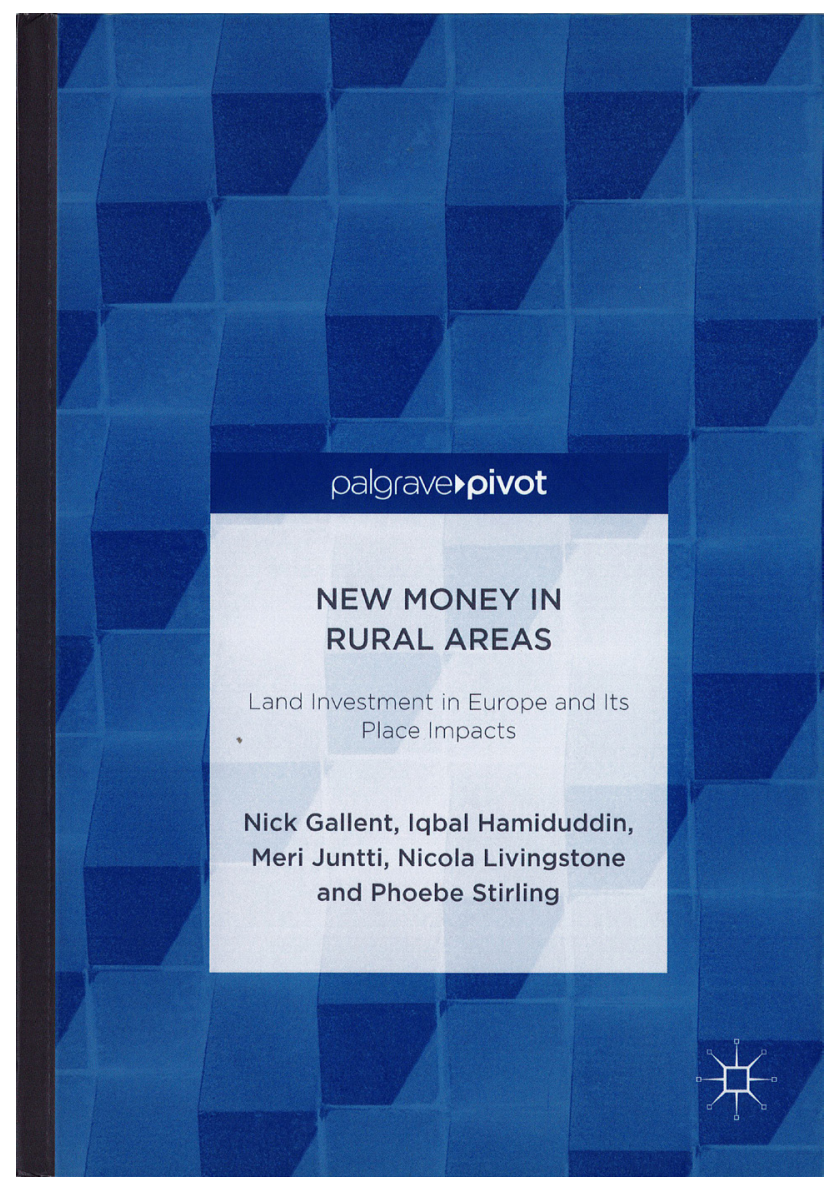


Jasno zastavljen okvir raziskovanja so preverjali z merjenjem sprememb v vrednostih in zalogah kapitalov (ekonomski, finančni, socialni, človeški, naravni, fizični). Le-te so spremljali preko različnih pokazateljev: kvantitativnih (število delovnih mest, prebivalstvena dinamika, načini upravljanja, kilometri izgrajene infrastrukture ipd.) in kvalitativnih (ki so temeljili na pogovorih s podjetji in lokalnimi skupnostmi). Učinke investicij so avtorji interpretirali z gospodarskega (ekonomska raba virov, lokalno podjetništvo), socialnega (razporeditev dobička in izgube, konflikti, spremembe v lastniški strukturi, razvoj skupnosti) in okoljskega vidika (ekosistemske storitve, okoljski problemi, ranljivost).

Avtorji so podrobno preučili deset študij primera, ki so jih razdelili v naslednje skupine:

- investicije, $v$ katerih se je nadaljevala predhodna raba tal, saj je bil investitor aktiven in se je odločil za neposredne investicije (vinogradništvo Sella\&Mosca na Sardiniji, pridelava žit Beeswax v Angliji, podjetje za pridelavo zelenjave Biosabor v španski Almeriji, Farmcare trading iz Združenega kraljestva),

- investicije, pri katerih je prišlo do drugačne rabe in so bili investitorji neposredni in aktivni (Trumpov mednarodni investicijski sklad v golfišče na Škotskem - TIGLS, zabaviščni park Moominov na Finskem, zelena vlaganja na Severnem Irskem, vinogradniško posestvo Evremond v angleškem Kentu, zasajevanje $\mathrm{z}$ vrbo na Finskem);

- investicije, kjer je prišlo do mešanega pristopa: ali neposredna investicija/aktivni investitor in neposredna investicija/pasivni investitor (primer AgriAD) ali primer neposredne investicije, a pasivnega vlagatelja (vlaganja nizozemske banke Rabo v Romuniji).

Avtorji ugotavljajo, da odgovori na dve začetni zastavljeni vprašanji (kako bi čim bolj maksimirali investicije na podeželju in kako bi različne negativne učinke čim bolj ublažili) nikakor niso preprosti. Ali bo investicija generirala dobrobit za vlagatelja in širšo skupnost, je odvisno tako od značilnosti vlagatelja kot njegovega interesa. Pomembno vlogo ima seveda zakonodaja, ki naj bi varovala lokalne interese in zagotavljala dobro prakso investiranja. Študije primera dokazujejo, da lahko pride do zlorab zakonodaje tako na lokalni kot na državni ravni in da je pogosto moč vlagateljev večja od obstoječe regulative. Obenem pa je treba izpostaviti, da se je v nekaterih primerih izkazala tudi moč dolgotrajnega in zavzetega ter sistematičnega dela lokalnih pobud (TIGLS).

Monografija je kombinacija teoretično-metodološkega uvoda, zanimivega in najobsežnejšega empiričnega opisa in analize desetih študij primerov ter krajšega zaključka. Predstavlja zanimivo branje zlasti za študente 2. in 3. stopnje, pa tudi vse deležnike in akterje, ki jih zanima, katere so nujne sestavine za učinkovite in trajnostno naravnane investicije na podeželju.

Irma Potočnik Slavič 


\section{RETHINKING PLACE BRANDING}

\section{Mihalis Kavaratzis, Gary Warnaby, Gregory J. Ashworth (uredniki): Ret- hinking Place Branding: Comprehensive Brand Development for Cities and Regions. Cham, Springer, 2015, 248 str.}

Današnji utrip človekovega življenja je močno zaznamovan od naraščajočih možnosti mobilnosti, komuniciranja in izmenjave tako snovnih kot tudi nesnovnih dobrin. Zdi se, da so se pod vplivom nove tehnologije razdalje med točkami v prostoru skrčile in da je vsem vse »na dosegu roke«. Proces globalizacije pa vendarle (še?) ni spremenil družb po posameznih pokrajinah sveta $\mathrm{v}$ gospodarsko in kulturno povsem povezano in uniformirano celoto. Globalizacija in z njo tesno povezano izginjanje lokalnih značilnosti v življenju ljudi sta hkrati sprožila tudi nasproten proces: vse bolj se poudarja poreklo izdelkov in storitev, lokalno pridelano in predelano hrano, krajevne navade in pristnost. Rezultat tovrstnega družbeno-gospodarskega razvoja je, da se danes vse bolj išče območja, kjer se je tradicija ohranila ali pa revitalizirala v najširšem pomenu besede: $v$ arhitekturi, kulinariki, gospodarstvu in kulturi.

Zbornik Rethinking Place Branding izhaja iz predpostavke, da so se pod vplivom tržnega gospodarstva razločevalne značilnosti posameznega območja pričele uporabljati kot priložnosti za njegovo trženje in privabljanje ne le turistov, temveč tudi raznolikih oblik kapitalov: finančnega, kulturnega, socialnega ... Posebnosti območja se pogosto poudarjajo $\mathrm{z}$ uporabo znamčenja - z razvojem in uporabo blagovnih znamk, ki pod svojim okriljem nudijo izdelke in storitve, ki so bolj ali manj značilni za določeno območje, na primer za turistično destinacijo, občino, zavarovano območje.

Avtorji pričujočega zbornika znamčenje območij obravnavajo tako s teoretskega vidika kot tudi z vidika aplikativnih pristopov. Zbornik je sestavljen iz šestnajstih poglavij, ki so jih napisali strokovnjaki z različnih področij: geografije, ekonomije, antropologije, komunikologije, politologije in umetnosti. Prvih pet poglavij je teoretskih: v uvodnih poglavjih se obravnava smiselnost proučevanja znamčenja območij (prvo poglavje) kot tudi izzive, ki jih prinašajo zelo raznolika teoretska in metodološka izhodišča posameznih ved (drugo poglavje). Znamčenje območij se kot pojav umesti tudi v prostorsko-časovni kontekst (tretje poglavje) $\mathrm{z}$ vidika teorije prostora in identitetnih vprašanj (četrto in peto poglavje).

Drugi del zbornika je bolj aplikativno naravnan, saj prinaša obravnavo študij primerov. Dve poglavji (šesto in sedmo) sta namenjeni razmisleku o vlogi tehnologije, medmrežja in digitalnih vsebin pri znamčenju območij. Ker je znamčenje območij lahko uspešno zgolj s sodelovanjem številnih deležnikov, je v zborniku predstavljena tudi teorija mrež in deležnikov (osmo poglavje). V preostalih poglavjih se obravnava posamezne elemente znamčenja območij, ki imajo vpliv na doseganje želenih učinkov: kulturo (deveto poglavje), ustvarjalnost (deseto poglavje), prilagajanje povpraševanju (enajsto poglavje), vizualizacijo (dvanajsto poglavje), kartografijo (trinajsto poglavje), 
vlogo čutil in zaznavanja (štirinajsto poglavje) in izzive "merjenja» ter vrednotenja učinkov znamčenja (petnajsto poglavje). V sklepnem poglavju, $s$ katerim avtorji pozivajo $\mathrm{k}$ tovrstnim raziskavam tudi v bodoče, so navedena raziskovalna izhodišča in doslej neodgovorjena raziskovalna vprašanja o znamčenju območij.

Zbornik je napisan $\mathrm{z}$ vidika predstavitve in razprave o rezultatih raziskovanj. Bralcu avtorji prispevkov predstavljajo svoja spoznanja o znamčenju območij in pogosto opozorijo na odprta in še neraziskana vprašanja. Zbornik primarno ni zasnovan zaradi izboljševanja upravljanja znamčenja, kjer bi avtorji uporabili »how to « pristop k pisanju, temveč z namenom kritičnega, a hkrati tudi konstruktivnega premisleka o pojavu. Kljub kritični naravnanosti pa so avtorji uspeli osvetliti kompleksno razpetost znamčenja med političnim, družbenim in navsezadnje tudi gospodarskim področjem. Pri pisanju se sklicujejo na primere iz prakse, kar bralcu olajšuje razumevanje vsebine.

Mihalis Kavaratzis · Gary Warnaby Gregory J. Ashworth Editors

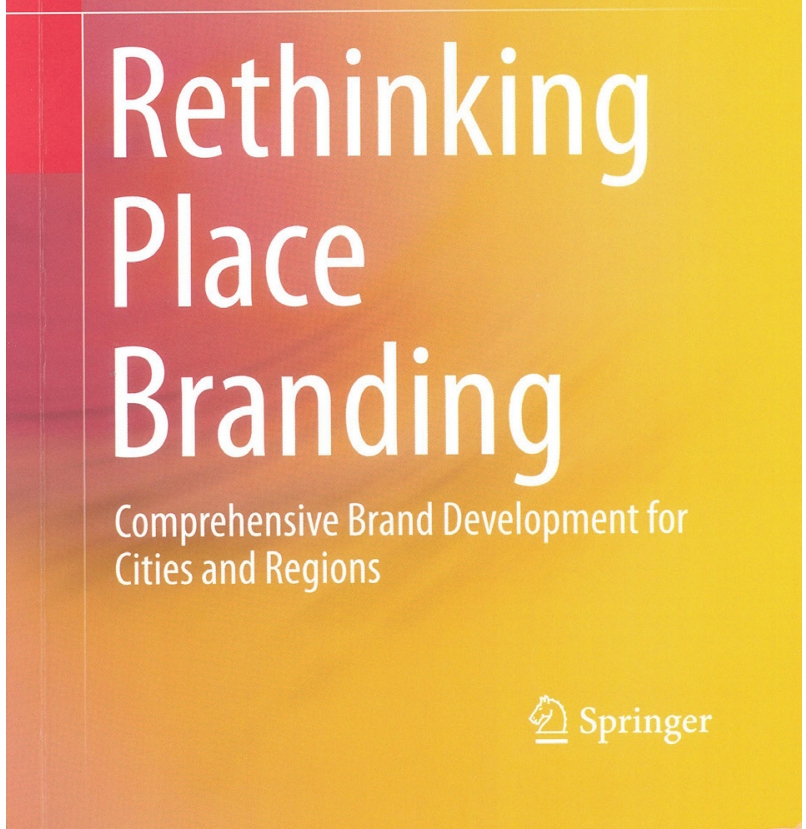


Zbornik geografu ne odkrije zgolj kompleksnosti znamčenja območij, ki se skriva pod navidezno enostavnimi blagovnimi znamkami, temveč posamezni prispevki zbornika poglobijo tudi geografovo znanje o teoriji prostora in okrepijo njegovo zavedanje o znamčenju kot mehanizmu razvoja območij. Znamčenje območij je še en dokaz, da človek prostor aktivno gradi ne le s snovnega (zgradbe, infrastruktura, krajina), ampak tudi z nesnovnega vidika (ideje, pomeni, zemljepisna imena).

Erik Logar

\title{
THE TASTE OF PLACE - A CULTURAL JOURNEY INTO TERROIR
}

\begin{abstract}
Amy B. Trubek: The taste of place: a cultural journey into terroir. Berkeley, University of California Press, 2009, 296 str.
\end{abstract}

V knjigi The taste of place: a cultural journey into terroir se je ameriška antropologinja Amy B. Trubek osredotočila na primerjavo tradicionalnih načinov priprave hrane ter uporabe lokalno pridelanih sestavin $\mathrm{v}$ izbranih lokalnih skupnostih in prehranskih podjetjih $\mathrm{v}$ Franciji in Združenih državah Amerike. Obravnavana tematika je z vidika proučevanja učinkov globalizacije na pokrajine in tamkajšnje lokalne skupnosti aktualna in tudi izzivalna - Francija ima namreč najstarejši in najbolj razvit sistem varovanja porekla hrane in vina na svetu, ki je postal vzor številnim državam, medtem ko Združene države Amerike veljajo za domovino "hitre« prehrane, ki je zaznamovana $\mathrm{z}$ »uniformirano« podobo in poenotenim načinom priprave jedi iz sestavin brez natančno opredeljenega porekla.

Knjiga je nastala $\mathrm{z}$ uporabo metode etnografskih opisov, ki v obliki študij primerov tvorijo posamezna poglavja. $\mathrm{V}$ posameznih poglavjih so predstavljeni primeri bolj ali manj uspešnih pobud za promocijo tradicionalnih načinov priprave hrane in uporabe lokalno pridelanih sestavin iz obeh držav.

$\check{Z}$ e v uvodu avtorica opozori, da $\mathrm{z}$ vidika proučevane tematike primerjava med Francijo in Združenimi državami Amerike ni preprosta in ne sme biti zaznamovana s "črno-belo« dihotomijo. V prvem poglavju avtorica razloži francoski koncept terroir (izraz je težko prevedljiv iz francoščine in bi ga morda lahko slovenili kot poreklo ali izvor) ter sistem varovanja porekla hrane in vina v Franciji. Delovanje tega sistema in odnos francoskih lokalnih skupnosti do porekla hrane in vina sta prikazana $\mathrm{v}$ drugem poglavju z zgodbo o neuspelem poskusu prodora globaliziranega ameriškega vinogradniškega podjetja Mondavi na francoski trg.

$\mathrm{V}$ tretjem, četrtem in petem poglavju so obravnavane posamezne pobude za promocijo uporabe lokalno pridelanih sestavin in tradicionalnih načinov priprave hrane 
in vina $\mathrm{v}$ restavracijah $\mathrm{v}$ ameriških zveznih državah Kalifornija in Vermont. V sklepnem, šestem poglavju pa avtorica razmišlja o možnostih ohranjanja tradicionalnih načinov priprave hrane in vina ter uporabe lokalno pridelanih sestavin $\mathrm{v}$ prihodnosti, ki jo bodo zaznamovali globalni tokovi informacij in dobrin, a se bo hkrati tudi okrepila zavest o veliki vrednosti in pozitivnih učinkih lokalno pridelane hrane tako za kupca kot tudi proizvajalca.

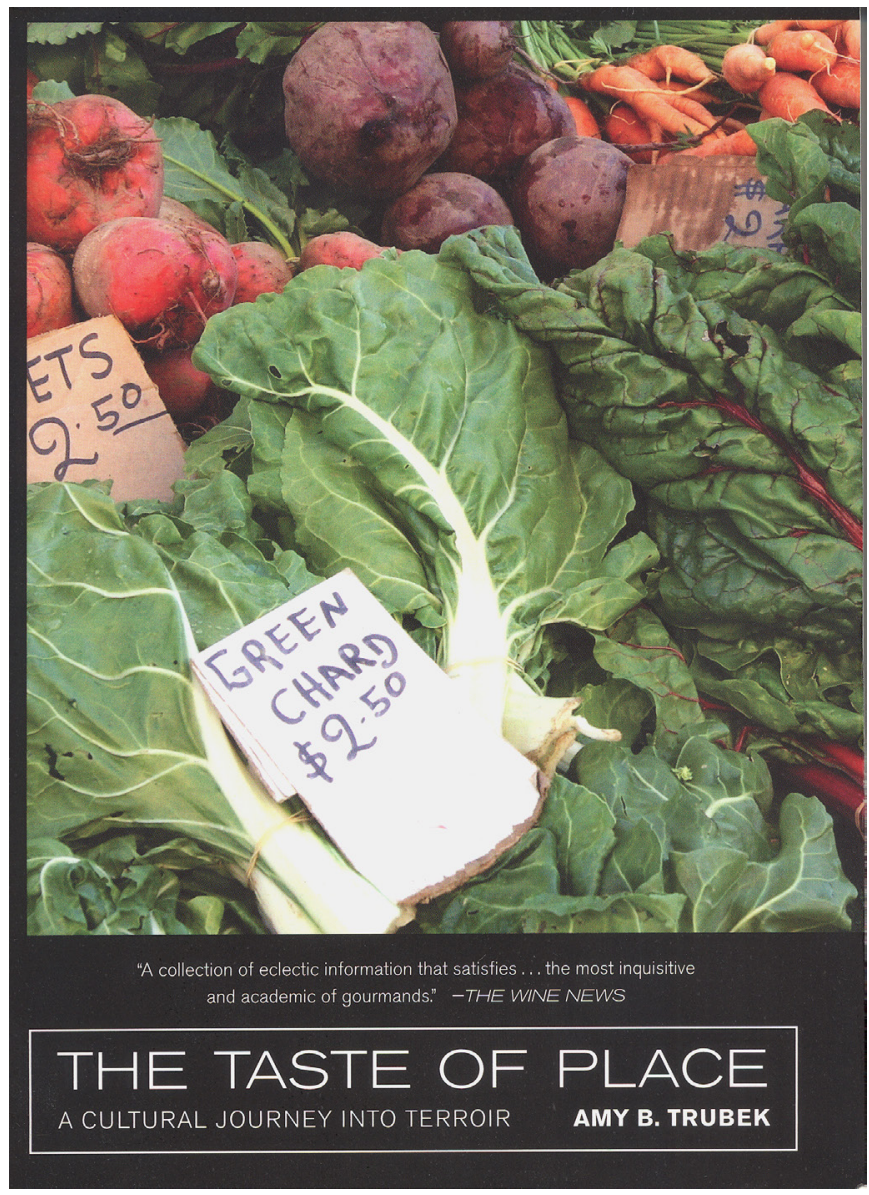

Avtorica v sklepu trdi, da bi morali tako na globalni ravni kot tudi po posameznih lokalnih skupnostih bolj ceniti in poudarjati vlogo lokalno pridelane hrane in vina. Hkrati ob upoštevanju globalnega tržnega sistema tudi ugotavlja, da bo v prihodnosti bolj kot geografsko zamejevanje pridelave in potrošnje na določeno prostorsko enoto (npr. občino, pokrajino) pri hrani pomembnejše natančno označevanje njenega porekla, načina pridelave ter prostorsko-časovne razsežnosti poti, ki jo je hrana opravila 
od pridelovalca do končnega porabnika. Avtorica zato ob koncu knjige namenoma ne odgovori na vprašanje: je hrana, ki jo sestavljajo sestavine z ustrezno označenim »nelokalnim« izvorom in ki je pripravljena po tradicionalnih receptih iz drugih pokrajin, manj kakovostna in zdravju bolj škodljiva kot hrana iz lokalnih sestavin in pripravljena po lokalnih tradicionalnih receptih?

\section{Erik Logar}

\section{KRATKA KRONIKA NEKEGA LETA: OBELEŽEVANJE NAŠE PRVE STOLETNICE}

Leto 2019 je bilo na Oddelku za geografijo Filozofske fakultete Univerze v Ljubljani zaznamovano $\mathrm{z}$ obeleževanjem 100-letnice kontinuiranega študija geografije v Sloveniji. Ko smo se pred leti pričeli pogovarjati o konceptu obeleževanja te 100-letnice kontinuiranega študija geografije na Filozofski fakulteti Univerze v Ljubljani, smo skušali odgovoriti na prvo ključno vprašanje: kako odgovorno in celovito pristopiti k bogati dediščini? Odločili smo se, da bo naš ključni prispevek monografija Razvoj geografije na Slovenskem - 100 let študija geografije na Univerzi v Ljubljani. Idejni pobudnik je bil Darko Ogrin (tudi urednik monografije), ki je vsebinsko zasnovo monografije pripravil v sodelovanju s Katjo Vintar Mally, Lucijo Miklič in Dejanom Cigaletom. Monografija je izšla v zbirki Filozofske fakultete Univerze v Ljubljani Historia facultatis. Monografija je razdeljena na pet poglavij, ki v časovnem loku od antike do sodobnosti sledijo razvoju geografske misli v svetu in njegovim odmevom v Sloveniji. 37 avtorjev različnih generacij je posredovalo strokovno utemeljen pogled na razvoj posameznih geografskih poddisciplin, raziskovalnih smeri, formaliziranega študija in (ne)formalnega povezovanja, s čimer je monografija posegla na področje zgodovine geografije, ki je v slovenski geografiji pogosto povsem neupravičeno spregledana. Tovrsten dosežek nam upravičeno zavidajo mnogo starejši in številčno (po številu pedagoških delavcev, raziskovalcev in študentov) močnejši geografski oddelki po svetu. Monografija prinaša številna spoznanja o razvoju geografske stroke, ki doslej niso bila poznana. Snovalci monografije se zavedajo, da je marsikaj ostalo prezrto in da naj knjiga služi tudi kot spodbuda geografom za angažiranje na področju raziskovanja ter kritičnega vrednotenja zgodovine naše vede. 
Monografija je celovit, problemsko zasnovan in v določenih delih tudi hudomušen prikaz razvoja geografije na Slovenskem.
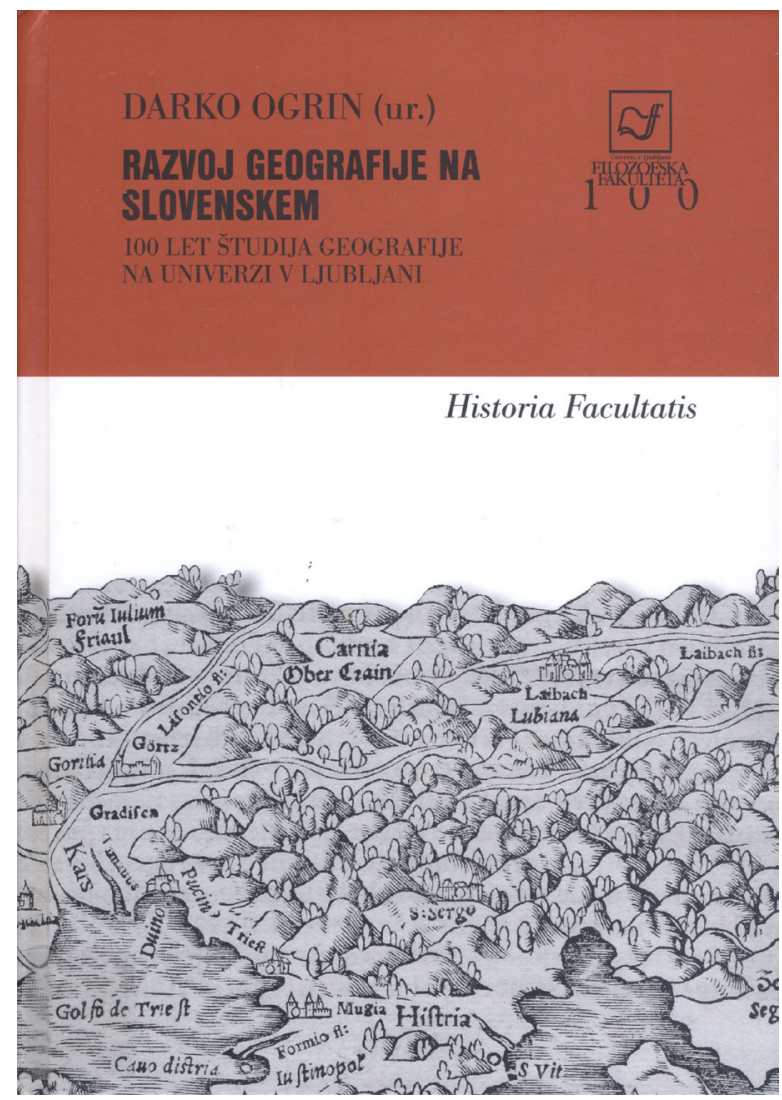

Filozofska fakulteta se je odločila, da bo kot ena izmed petih soustanoviteljic Univerze v Ljubljani, celovito pristopila k obeleženju 100-letnice, zato je izdala Slavnostni zbornik, izvedla slavnostno in vsebinsko bogato akademijo (september 2019), obenem pa v sodelovanju z oddelki izvedla več kot 100 različnih dogodkov. Na Oddelku za geografijo smo glede tega izstopali v pozitivno smer, organizirali smo 12 dogodkov, ki smo jih skušali enakomerno razporediti po koledarskem letu. Ko smo pričeli sestavljati koncept tovrstne oblike obeleženja 100-letnice, smo si zastavili drugo vprašanje: kako nasloviti raznovrstna geografska področja, na katerih delujemo? Odločili smo se, da bomo skušali strokovni in širši javnosti predstaviti aktualne tematike, s katerimi se sodelavke in sodelavci raziskovalno ukvarjamo. Tako smo se ukvarjali z ledeniki v Sloveniji, z viri onesnaženja zraka, poplavami kot delom našega vsakdana, gorami v slovenski identiteti, prstmi in njihovim poimenovanjem, trajnostno rabo regionalnih virov, skritimi geografijami, največjimi zakladi geografske knjižnice, novimi pristopniki v kmetijstvo, 
romskimi naselji, geopolitičnimi perspektivami in izzivi Slovenije ter didaktiko geografije $\mathrm{v}$ času in prostoru. Tematike smo obravnavali na raznovrstne načine: večkrat smo se odločili za niz predavanj z diskusijo, raznovrstna mnenja so se soočila ob več okroglih mizah, celovit pregled so omogočale razstave, udeleženci so aktivno sodelovali na delavnicah, poletni šoli in mednarodni konferenci. Po naših podatkih so bili dogodki

Organigram dogodkov, ki smo jih izvedli v sklopu obeleženja 100-letnice (oblikovanje: T. Sabec).

DOGODKI OB OBELEŽENJU 100- LETNICE ODDELKA ZA GEOGRAFIJO, FF UL

\section{LEDENIKI V SLOVENIJI predavanja in razstava}

17. 1. 2019 ob $18: 00$ predavalnica 233 , Oddelek za geografijo, FF UL

\section{POPLAVE SO DEL NAŠEGA VSAKDANA predavanja, okrogla miza in razstava}

21. 3. 2019 ob 11:00 predavalnica 233 , Oddelek za geografijo, FF UL

PRSTI MED SLOVENIJO IN ESTONIJO in njihovo poimenovanje razstava

april 2019 Oddelek za geografijo, FF UL

\section{SKRITE GEOGRAFIJE}

mednarodna konferenca EUROGEO in llešičevi dnevi

29. 8. - 31. 8. 2019

Zdravniška zbornica Ljubljana
LOKALNI, REGIONALNI

IN GLOBALNI VIRI

ONESNAŽENJA ZRAKA

strokovni posvet

5. 2. 2019 ob 9:00 Modra soba, FF UL

\section{GORE V NACIONALNI \\ IDENTITETI SLOVENIJE \\ IN ČRNE GORE \\ predavanja in razprava}

3. 4. 2019 ob 13: 00 Modra soba, FF UL

\section{TRAJNOSTNA RABA \\ REGIONALNIH VIROV \\ poletna šola mreže \\ GEOREGNET}

1. 7. - 12.7. 2019

Oddelek za geografijo, FF UL

MEDNARODNA VPETOST ODDELKA ZA GEOGRAFIJO

razstava $v$ angleškem jeziku

julij in avgust 2019

Oddelek za geografijo, FF UL 
dobro obiskani (v povprečju 50-70 udeležencev); veseli pa smo, da se je pogosto razvila živahna razprava (formalna in tudi po dogodku). Zavedamo se, da nekaterih zelo aktualnih geografskih tematik $v$ jubilejnem letu nismo uspeli uvrstiti na program, zato bomo tovrstne vsebine naslavljali tudi v naslednjih letih.

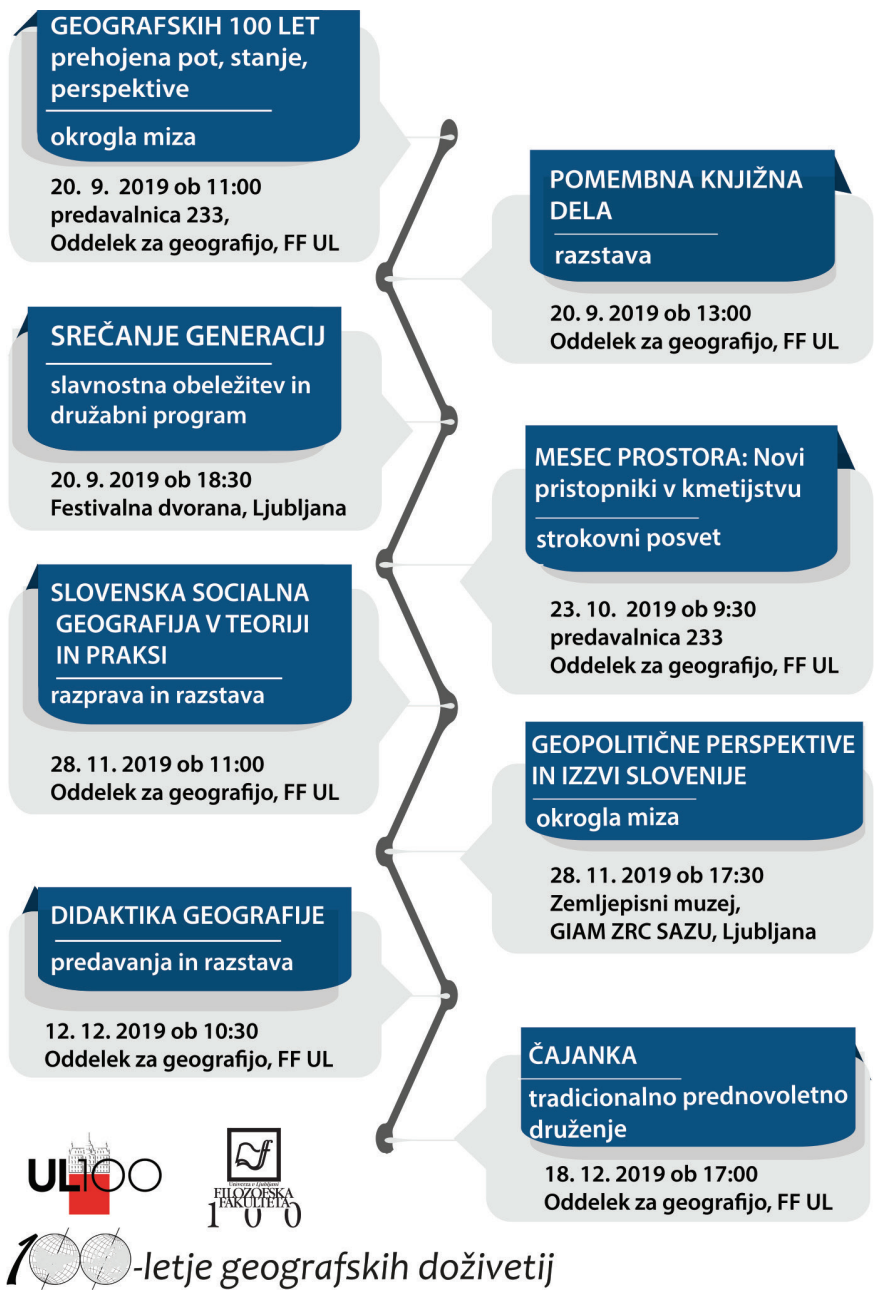


Ob oblikovanju koncepta in časovnice zgoraj navedenih dogodkov smo se soočili s tretjim vprašanjem: kako nasloviti domačo in tujo strokovno javnost? Skušali smo vključiti strokovnjake in organizacije, $s$ katerimi sodelujemo, $s$ čimer je prišla do izraza inter- in transdisciplinarna razsežnost našega dela. Pri zasnovi in izvedbi dogodkov so pomembno sodelovale geografske ustanove in združenja: Geografski inštitut Antona Melika ZRC SAZU, Oddelek za geografijo Univerze v Mariboru, Oddelek za geografijo Univerze na Primorskem, Inštitut za raziskovanje krasa, Zveza geografov Slovenije - ZGS, Ljubljansko geografsko društvo, Društvo učiteljev geografije - DUGS, Komisija za hidrogeografijo pri ZGS, AGUL - Alumni klub geografov Univerze v Ljubljani in Društvo mladih geografov Slovenije. Povezovali smo se z drugimi fakultetami in raziskovalnimi inštitucijami (Biotehniška fakulteta, Fakulteta za družbene vede, Inštitut Jožef Štefan), deležniki na nacionalni (ministrstva: MKGP, MGRT, Služba vlade za razvoj in kohezijsko politiko, MOP; agencijami: Agencija RS za okolje) in lokalni ravni (Mestna občina Ljubljana, Mestna občina Koper, Občina Loški potok, Občina Trebnje, Občina Kočevje, Občina Domžale, Občina Vitanje), $z$ različnimi ustanovami (Naravni rezervat Škocjanski zatok, Slovenski regionalni razvojni sklad, Zadružna zveza Slovenije, Center vesoljskih tehnologij Hermana Potočnika Noordunga, Vitanje) in predstavniki civilne družbe (Focus, CIPRA Slovenija, Društvo za razvoj slovenskega podeželja itd.). Pri izvedbi dogodkov je vedno pomagala tudi matična Filozofska fakulteta: s finančnim prispevkom, tehnično podporo (ozvočenje, fotografiranje, oglaševanje, prevozi, urejanje prostora) in veliko podporo g. dekana (številni tematski nagovori, obiski prireditev).

Oddelek za geografijo je že od same ustanovitve precejšnjo pozornost namenjal mednarodnim povezavam. Trenutno oddelek preko medknjižničnih izmenjav (Geografski vestnik, Dela in monografije iz zbirke GeograFF) posreduje publikacije na več kot 120 naslovov v 32 državah), sodeluje v mednarodnih raziskovalnih projektih (v zadnjih 15 letih: 16 bilateralnih projektov; 14 mednarodnih projektov, ki imajo v povprečju med 7 do 14 partnerjev) in mednarodnih izmenjavah študentov, učiteljev in strokovnih sodelavcev ( $\mathrm{v}$ dvajsetih letih smo sodelovali na podlagi bilateralnih pogodb z več kot 50 geografskimi oddelki v sklopu programa Erasmus). Na podlagi te široke mreže povezav smo ob soorganizaciji z DUGS-om in Evropsko zvezo geografov (EUROGEO) naslovili domačo in tujo strokovno javnost. Mednarodna konferenca Skrite geografije in Ilešičevi dnevi so konec avgusta z uvodnimi predavanji, številnimi sekcijami, razpravami in strokovno ekskurzijo združevali več kot 150 geografov z vsega sveta. V letu 2020 bodo v tiskani obliki, in sicer kot znanstveno monografijo in tematsko številko Evropske revije za geografijo (oboje pri založbi Springer), predstavili osrednjo tematiko konference. 
Ključne informacije o Poletni šoli, ki so se je udeležili študentje in učitelii, vključeni v geografsko mrežo GeoRegNet (oblikovanje: A. Seifert Barba).

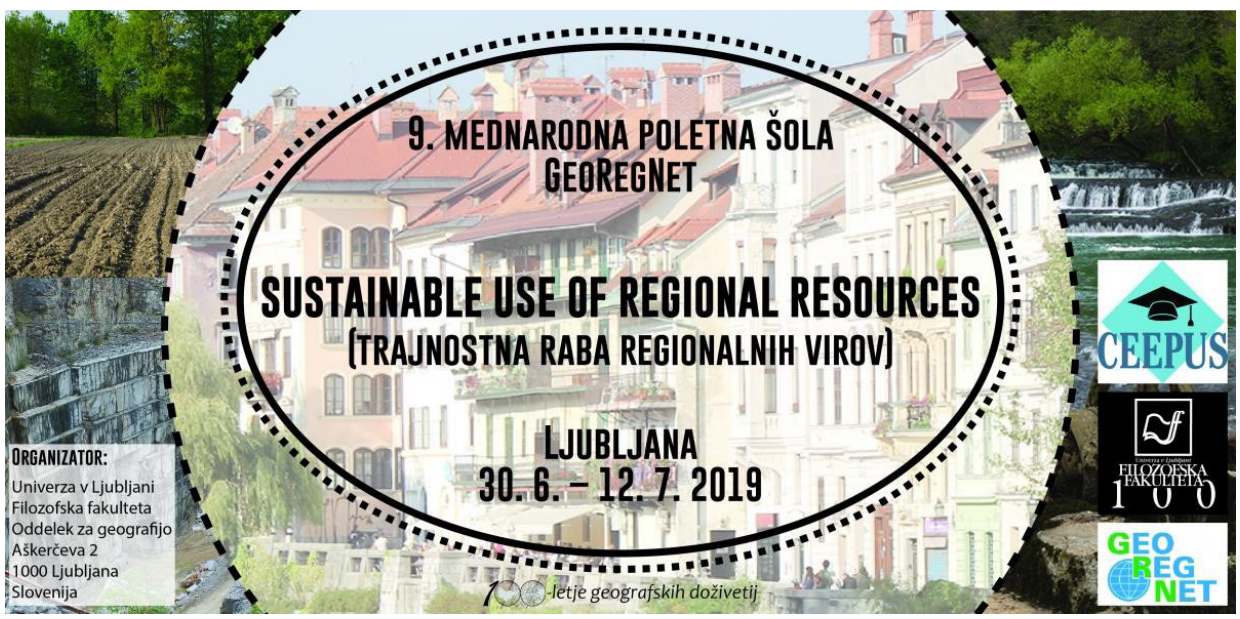

Oddelek za geografijo je v toku zadnjih 100 let naziv diplomirani geograf/inja, univerzitetni diplomirani geograf/inja, profesor/ica geografije, magister/magistrica geografije podelil 2400 diplomantom. Pripravljalni odbor za organizacijo vseh dogodkov (10 članov, 17 sej) si je tako zastavil četrto vprašanje: kako nasloviti različne generacije geografov? Za ta namen smo že v letu 2018 pričeli z izdajanjem e-novičnika Geografska širina, na katerega se je ob upoštevanju določil GDPR priglasilo 1000 geografov/ inj, ki smo jih obveščali in vabili na dogodke, seznanjali z novicami in novostmi na oddelku ter skupaj z njimi delili zanimive utrinke iz študija geografije. Posneli smo tudi 10-minutni film, v katerem je osem vidnih geografov/inj podalo zanimive odgovore (Kaj mi je dala geografija? Kaj sem dal/a geografiji?), podrobnosti svojih razmišljanj o preteklih poteh in poslanstvu geografije v prihodnje pa delilo še na okrogli mizi (20. 9. 2019). Obenem smo se poslužili že uspešnega koncepta Srečanja generacij, ki je privabil stanovske kolegice in kolege že ob 80 - in 90-letnici našega oddelka. V soorganizaciji z AGUL-om smo v septembru 2019 privabili 336 geografov vseh generacij (od tistih, ki so se vpisali leta 1952, do tistih, ki so se vpisali šest desetletij kasneje). Na podlagi številnih odzivov sklepamo, da je bil svečano-družabni dogodek prijeten in da bi bilo tradicijo tovrstnih srečevanj smiselno ohranjati. Tudi na tem dogodku se je pokazala vpetost geografov/inj v prostor: za naš geografski srečelov je doniralo (v obliki finančne donacije, izdelkov ali storitev) kar 100 donatorjev, brez katerih celotnega dogodka ne bi zmogli izvesti in smo jim iskreno hvaležni. Hkrati pa smo geografi donirali sredstva za nakup šolskih pripomočkov pri pouku geografije v Centru za izobraževanje, rehabilitacijo, inkluzijo in svetovanje za slepe in slabovidne v Ljubljani. 
Plakat, ki je vabil geografe na jubilejno Srečanje generacii v Festivalni dvorani (oblikovanje: A. Seifert Barba).

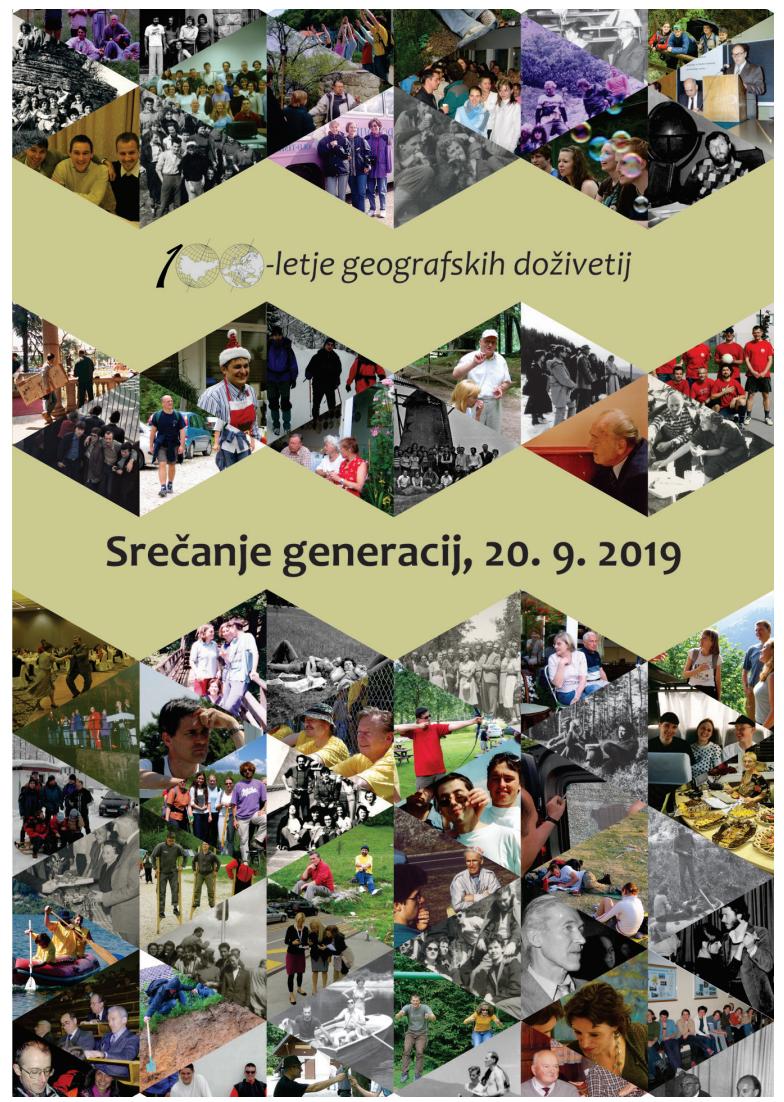

Z vsemi dogodki smo želeli slediti tudi osnovnemu poslanstvu oddelka, tj. prenosu znanj. Organizatorje je tako zaposlovalo peto vprašanje: kako nasloviti mlajše generacije? Ker na splošno v današnjem času več posegamo po elektronskih virih, so sodelavke knjižnice Oddelka za geografijo (ob pobudi D. Ogrina) pripravile digitalni katalog in razstavo o 100 največjih zakladih naše knjižnice. Tako zdaj s klikom spoznavamo ključna dela, pomembna za razvoj naše stroke (povezava: http://geo.ff.uni-lj.si/knjiznica/galerija_knjiznih_del\#overlay-context=knjiznica/knjiznica). Z organizacijo poletne šole mednarodne CEEPUS geografske mreže GeoRegNet, ki povezuje 17 univerz Srednje, Vzhodne in Jugovzhodne Evrope (julij 2019), smo povezali več kot 20 študentov teh ustanov, ki so 14 dni preučevali trajnostno rabo regionalnih virov. Pri tem so jim s svojimi pogledi in izkušnjami pomagali tuji (s Češke, Poljske, Bosne in Hercegovine ter Združenih držav Amerike) in domači predavatelji. Obiskali so različne organizacije, najbolj dragoceno pa je bilo terensko raziskovanje v občini Vitanje, po Ljubljani, v Domžalah in na Obali. Že tradicionalno pa v 
decembru za študente in z njimi organiziramo čajanko: letos smo že 18. leto sledili izvirni ideji dr. Metke Špes. Prijetnemu druženju s čajem in doma spečenimi piškoti, na okrašenem hodniku, ob podelitvi priznanj najboljšim študentskim delom in pregledu rezultatov prednovoletne ankete smo ob zabavnem geografskem kvizu ter v sproščeni terenski opremi drug drugemu zaželeli veliko uspehov in vse dobro v prihodnjem letu.

Srečanje ob čaju in domačih piškotih ter v dobri družbi - to je geografska čajanka (foto: $N$. Kavka, 2019).

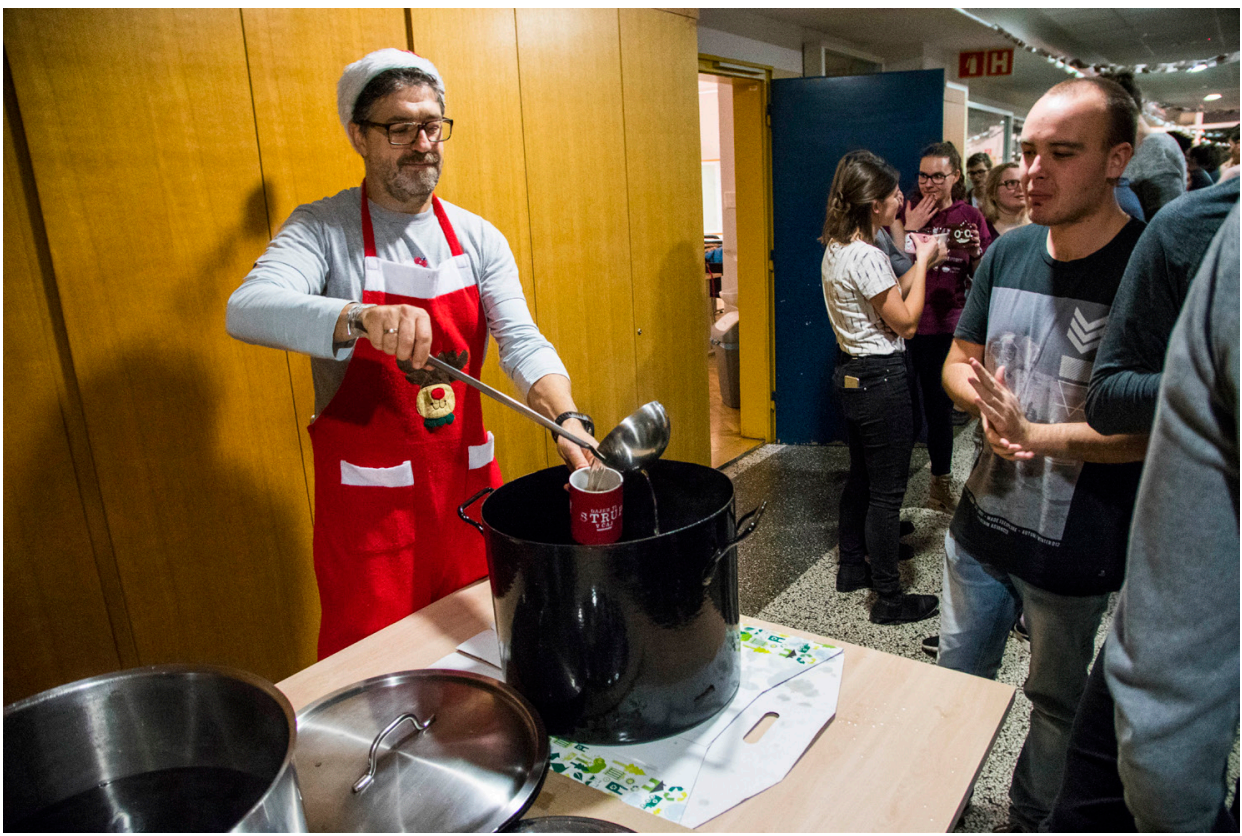

Vtisov je preveč, da bi jih lahko strnili v ta kratek zapis. Pomembno sporočilo o odmevnosti naših prizadevanj pa so nam posredovali tudi naši študenti, ki so v prednovoletni anketi $(\mathrm{N}=114)$ zapisali, da jim je bilo všeč, ker je bilo v letu 2019 veliko dogodkov in dogajanja ob 100-letnici, da so bili veseli, ker so se jih lahko udeleževali, da so še bolj zadovoljni, ker so lahko pri njihovem načrtovanju in izvedbi aktivno sodelovali. Vsem, ki ste pri obeleženju 100-letnice Oddelka za geografijo FF UL sodelovali na kakršen koli način, se iskreno zahvaljujemo in upamo, da bomo na različne načine sodelovali tudi v prihodnje. V tem poročilu posredujemo le kratek pregled, celovit vpogled v celoletno dogajanje pa bomo predstavili v posebni e-publikaciji, ki bo objavljena na spletni strani v letu 2020.

Irma Potočnik Slavič 


\section{MEDNARODNA KONFERENCA SKRITE GEOGRAFIJE}

\section{Ljubljana, 29.-31. avgust 2019}

Oddelek za geografijo Filozofske fakultete Univerze v Ljubljani je v okviru praznovanja 100-letnice ustanovitve oddelka pod okriljem Evropske zveze geografov EUROGEO in Društva učiteljev geografije Slovenije v času od 29. do 31. avgusta 2019 organiziral mednarodno konferenco Hidden Geographies (Skrite geografije).

Mednarodne konference se je udeležilo blizu 150 udeležencev in udeleženk iz 32 držav (Albanija, Avstralija, Avstrija, Belgija, Bosna in Hercegovina, Brazilija, Bolgarija, Kanada, Čile, Kitajska, Češka republika, Gruzija, Nemčija, Madžarska, Iran, Italija, Japonska, Južna Koreja, Nova Zelandija, Poljska, Romunija, Rusija, Srbija, Slovenija, Republika Južna Afrika, Španija, Tajvan, Nizozemska, Turčija, Ukrajina, Velika Britanija, Združene države Amerike).

Neformalno druženje udeležencev in udeleženk v času odmora (foto: arhiv Oddelka za geografijo FF UL).

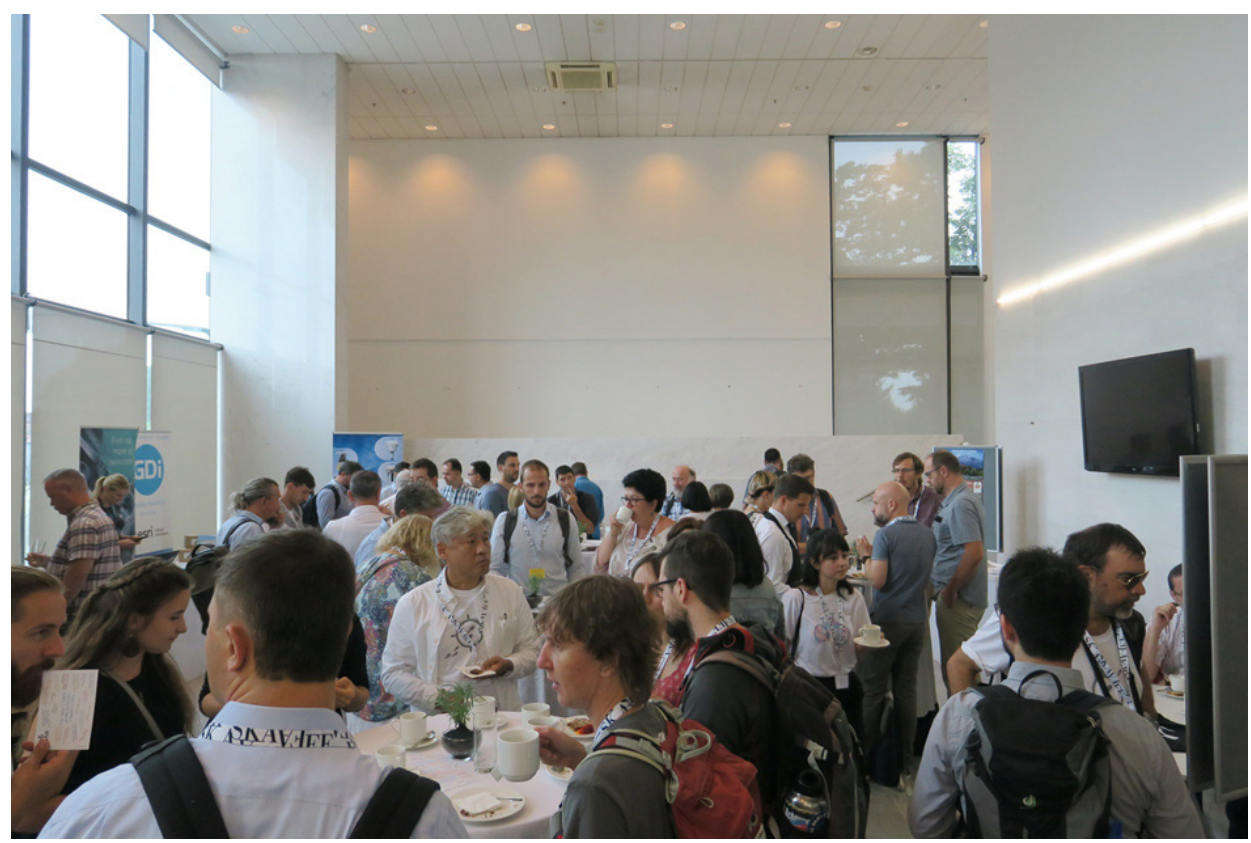

V času konference je bilo izvedenih 113 predavanj, 6 delavnic, predstavljenih je bilo 25 posterjev. V okviru mednarodne konference so se udeleženci odpravili tudi na celodnevno ekskurzijo v Škocjanske jame, Štanjel in Goče. 
Udeležence je na strokovni ekskurziii vodil Uroš Stepišnik (vhod pred Škocjanskimi jamami) (foto: M. Ilc Klun).

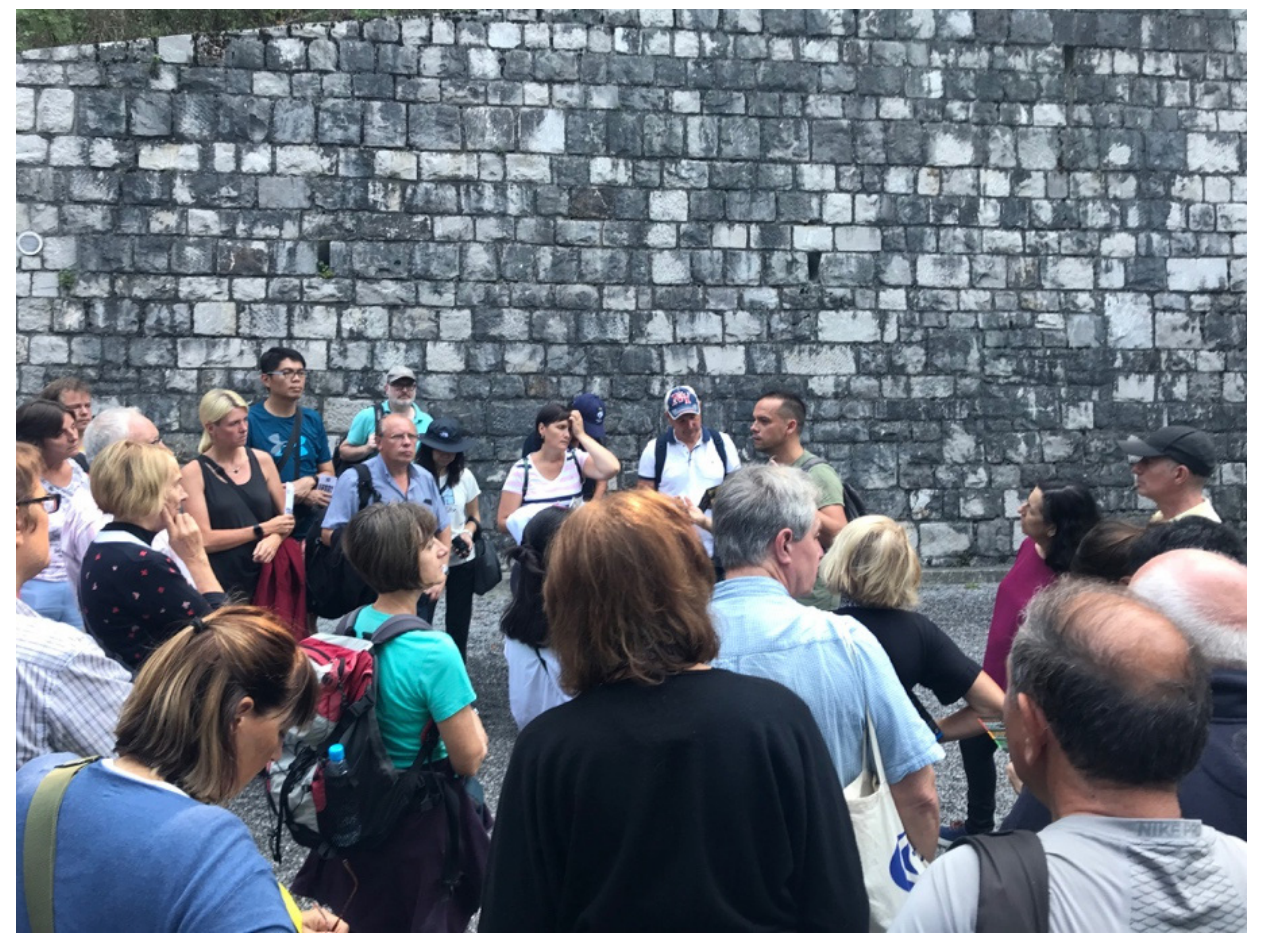

Mednarodno konferenco so sooblikovali štirje vabljeni predavatelji. Tracey McKay je udeležencem spregovorila o skritih geografijah izobraževanja bodočih učiteljev na primeru vsebin Muzeja dediščine Oranžnega reda v Belfastu na Severnem Irskem. Andrej Mihevc je obravnaval skrite kraške pokrajine Slovenije. Gerry O'Reilly je spregovoril o skritih geografijah v času sprememb in konfliktov, Josef Strobl pa o geografiji s poudarkom na geomedijih kot vmesnikih za razmišljanje o prostoru.

Konferenca je ponudila priložnost za razprave o skritih geografijah, zaznavanju in razumevanju le-teh, zavedanju njihovega obstoja na vseh ravneh - tako na področju družbene in fizične geografije, geografskih informacijskih sistemov kot tudi v izobraževanju. Raznovrstnost predavanj, delavnic in posterjev je nedvomno obogatila tako slovenski kot mednarodni geografski prostor. 


\section{0-LETNICA ROJSTVA DR. VLADIMIRJA BRAČIČA IN MONOGRAFIJA O HALOZAH}

11. oktobra 2019 je Oddelek za geografijo Filozofske fakultete Univerze v Mariboru praznoval 100-letnico rojstva prof. dr. Vladimirja Bračiča, enega od očetov mariborske univerze in tudi geografije na njej. Precej burno življenje tega znamenitega geografa so zaznamovale Haloze, vinorodna pokrajina južno od Drave, ki je prav po njegovi zaslugi postala širše znana in geografsko proučena, sam pa se je uveljavil kot eden vidnejših predstavnikov slovenske socialnogeografske šole. Mariborski kolegi so okroglo obletnico zaznamovali s tremi medsebojno povezanimi aktivnostmi: z znanstvenim simpozijem, z znanstveno monografijo in razstavo o dr. Bračiču.

Vladimir Bračič je tako ne le začetni in morda ključni proučevalec Haloz, temveč tudi nekakšen »zavetnik« regije, saj je o njej kot domačin pisal tudi zaradi družbene angažiranosti. Medsebojno povezana Bračičev življenjski cikel in raziskovalni opus sta $\mathrm{v}$ monografiji predstavljena v razširjenem uvodnem delu. Bračič (rojen $1919 \mathrm{v}$ Cirkulanah) je po učiteljišču začel svojo poklicno pot kot učitelj. To kariero je prekinila druga svetovna vojna, $\mathrm{v}$ kateri je preživel vlogo interniranca in se pozneje aktivno vključil v partizansko gibanje. Dosegel je pomembne vojaške uspehe, a se po vojni vrnil v učiteljske vode, vmes doštudiral geografijo na Univerzi v Ljubljani, kjer je leta 1965 tudi doktoriral. Po uspešni karieri srednješolskega profesorja in ravnatelja je spričo družbene angažiranosti postopoma pričel uresničevati idejo: oblikovati univerzo v Mariboru! Ta zamisel mu je tudi uspela (1975) in pripadla mu je čast prvega, ustanovnega rektorja. Bračič se s tem postavlja med vidne šolnike slovenskega prostora in je prototip geografa, ki je usmerjen $\mathrm{k}$ aplikacijam. Mariborski kolegi so se - kot dediči Bračičeve bogate raziskovalne zapuščine - ob 100-obletnici njegovega rojstva tako zelo primerno oddolžili z monografijo, ki posreduje sodobna razvojna vprašanja te vinorodne regije z značilnim gričevnatim pejsažem. Monografija "Kulturna pokrajina Haloz« predstavlja referenčno delo za naš čas in vzhodnoslovenski prostor.

Monografijo (220 strani, 10 avtorjev, izdana v zbirki: Prostori) so uredili V. Drozg, U. Horvat in E. Konečnik Kotnik. Prvi del monografije je poseben z vsebinskega in metodološkega vidika: različni avtorji so pripravili obširen in natančen oris Bračičevega strokovnega opusa, ki se še posebej reflektira $\mathrm{z}$ raziskavami v Halozah. Ta natančen vpogled predstavlja dragoceno popotnico k pregledu slovenske geografske bibliografije in Bračičeve biografije. Drugi del se po poglavjih posveča različnim vidikom proučevanja Haloz in podaja izsledke empiričnih študij, v katerih so avtorji uporabili različne metodološke pristope. Prispevki o kmetijstvu, spremembah rabe tal, značilnostih prsti in odprtih okoljskih vprašanjih, demografskem razvoju, turističnih virih, temelječih na starih (kmetijstvo s poudarkom na vinsko-sadnih usmeritvah) in novih (pohodne in kolesarske poti, tematizacija lokalne kulturne dediščine), so nakazali, s čim je mogoče zavreti negativne gospodarske in demografske procese ali pa regijo celo potegniti iz 
marginalnosti. Racionalen uvid je nujni predpogoj za primerno in trezno trasiranje razvojnih paradigem, seveda ob predpostavki, da se za to aktivirajo tako lokalni (haloški) človeški viri kakor tudi sistemski ukrepi najmanj širše slovenske regionalne ter državne ravni. Zadnji del predstavlja teoretično-metodološko razpravo: če govorimo, kdo in na kakšen način ustvarja in vzdržuje kulturno pokrajino, je ob prepoznavanju problemov mogoče snovati tudi konstrukcije njihovega preseganja. Ta del zelo posrečeno in simbolno zaokroža monografijo, vračajoč se k naslovnemu izzivu: kulturni geografiji.

Izjemno lepo organiziranemu ter dobro obiskanemu dogodku (tako s strani Univerze v Mariboru kot njegove Filozofske fakultete) je posebno noto dodala tudi prisotnost Bračičevih stanovskih kolegov - dr. Božidarja Kerta, dr. Boruta Belca in dr. Mirka Paka ter predstavnikov razvojnih ustanov iz Haloz. Dogodek je tako zaznamovala tudi živahna strokovna diskusija, usmerjena predvsem k Halozam: kulturni pokrajini s perspektivami in optimizmom, ne le (včasih kar preveč ukoreninjeno) predstavo o ubožnosti periferije.

\section{Jernej Zupančič, Dejan Cigale in Irma Potočnik Slavič}

Prizor z znanstvenega simpozija, ki je potekal 11. oktobra 2019 v prostorih Filozofske fakultete Univerze v Mariboru (foto: I. Potočnik Slavič).

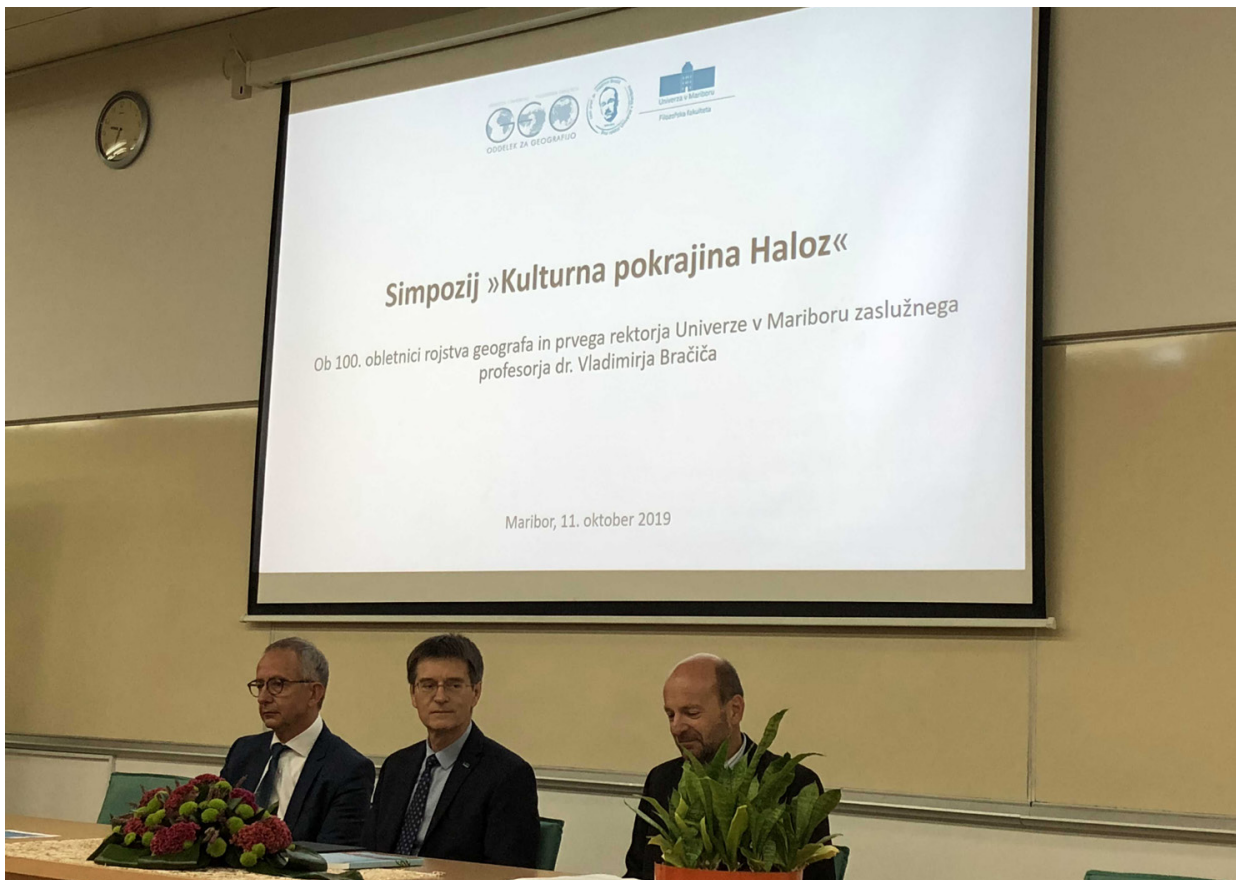




\section{RAZVOJ PODEŽELJA IN LEADER: PRIROČNIK IN MEDNARODNA KONFERENCA}

Na področju razvoja podeželja je LEADER iz pilotne pobude Evropske unije v 28 letih delovanja prerasel v pomemben program (ima svojo metodo, način financiranja, teritorij, strukture ipd.). LEADER metoda temelji na sedmih načelih: na pristopu od spodaj navzgor, ki se izvaja na LEADER ozemlju (teritorialni pristop), na katerem se deležniki povežejo v partnerstvo (lokalna akcijska skupina), da bi v skladu z razvojnim dokumentom (lokalna razvojna strategija) pripravili inovativne projekte in dosegli medsektorsko povezovanje, pa tudi sodelovali z drugimi lokalnimi akcijskimi skupinami v državi in v mednarodnem okolju.

Slovenija je s politiko razvoja podeželja pričela v začetku 90 -ih let 20. stoletja, kar je predstavljalo odlično podlago za izvedbo programa LEADER, s katerim je Slovenija začela v programskem obdobju 2007-2013. V 33 slovenskih lokalnih akcijskih skupinah je bilo izvedenih več kot 1400 projektov in investiranih več kot 30 milijonov $€$. V programskem obdobju 2014-2020 v Sloveniji deluje 37 lokalnih akcijskih skupin, programu LEADER/CLLD je namenjenih 95 mio $€$ sredstev.

$\mathrm{Na}$ Oddelku za geografijo se s tematiko LEADER-ja poglobljeno ukvarjamo, saj jo vključujemo v učni načrt pri vsebinah s področja geografije podeželja. Obenem pa smo v sklopu mednarodnega Erasmus+ projekta (TELI 2: Transnational Education in LEADER Implementation; več na povezavi: http://teli2.eu/) izdelali mednarodni program usposabljanja za LEADER. Le-ta je nastal v dvoletnem sodelovanju z lokalnimi akcijskimi skupinami iz Slovenije (LAS med Pohorjem in Bohorjem), Irske (SECAD: South-East Cork Development), Romunije (LAS Dobrogea), Portugalske (ADRIMAG in MONTE), Poljske (Dolina Raby) ter Hrvaške (LAS Zeleni bregi, LAS Zrinska Gora-Turpolje) ter dvema izobraževalnima ustanovama (Limerick Institute of Technology z Irske in Oddelek za geografijo FF UL). Zasnovo programa za usposabljanje smo pripravili na podlagi mednarodne raziskave, ki je skušala ugotoviti, katere vsebine izvajalci programa LEADER najbolj pogrešajo pri svojem delu. Tako smo razvili program, ki vključuje temeljne poteze razvoja podeželja, programa LEADER in komunikacijskih spretnosti, ki smo ga za prve študente že izvedli v letih 2017 in 2018. Udeleženci so bili z njim zelo zadovoljni, saj je zanimiva kombinacija teoretičnih in praktičnih vsebin, izvajal se je preko e-učenja, a tudi na terenu (tri enotedenske delavnice na Irskem, Portugalskem in Poljskem), naloge so bile praktično naravnane. Priročnik v slovenskem jeziku si lahko ogledate na: http://teli2.eu/teli2-learning-portal/teli2-training-handbook/.

Ker pa je bil LEADER - kot program in metoda - na mednarodni ravni prepoznan kot inovativen in učinkovit, vzporedno s širjenjem Evropske unije poteka tudi širjenje programa LEADER v države Jugovzhodne Evrope. Prva mednarodna konferenca (Opatija, 20.-22. 11. 2019; povezava: https://www.see-leader.eu/) je z več kot 300 udeleženci obravnavala tako praktične kot teoretične vidike izvajanja LEADER-ja, ki je v 
programskem obdobju 2014-2020 (ko se imenuje LEADER/CLLD - lokalni razvoj, ki ga vodi skupnost; https://www.program-podezelja.si/sl/) prisoten v več kot 3300 lokalnih akcijskih skupinah na podeželju, ribiških območjih in tudi že v nekaterih mestih v državah članicah Evropske unije.

Predavatelji so predstavili izvajanje LEADER-ja v državah, ki imajo bogate in tudi začetne tovrstne izkušnje, predstavili so tudi izkušnje različnih ravni (EU, državne, regionalne, lokalne) odločanja, pa tudi kritične znanstvene poglede na učinke LEADER-ja. Hkrati so imeli udeleženci možnost za mreženje (predstavitve lokalnih akcijskih skupin, tematski terenski ogledi, diskusije) in potencialno skupno pripravo projektov v prihodnje.

$V$ sklopu 1. mednarodne konference o LEADER-ju v državah Jugovzhodne Evrope je več kot 300 udeležencev sodelovalo $v$ različnih aktivnostih (plenarna predavanja, sekcije, terenski ogledi, predstavitve posterjev, mreženje, zaključna razprava; foto: I. Potočnik Slavič).

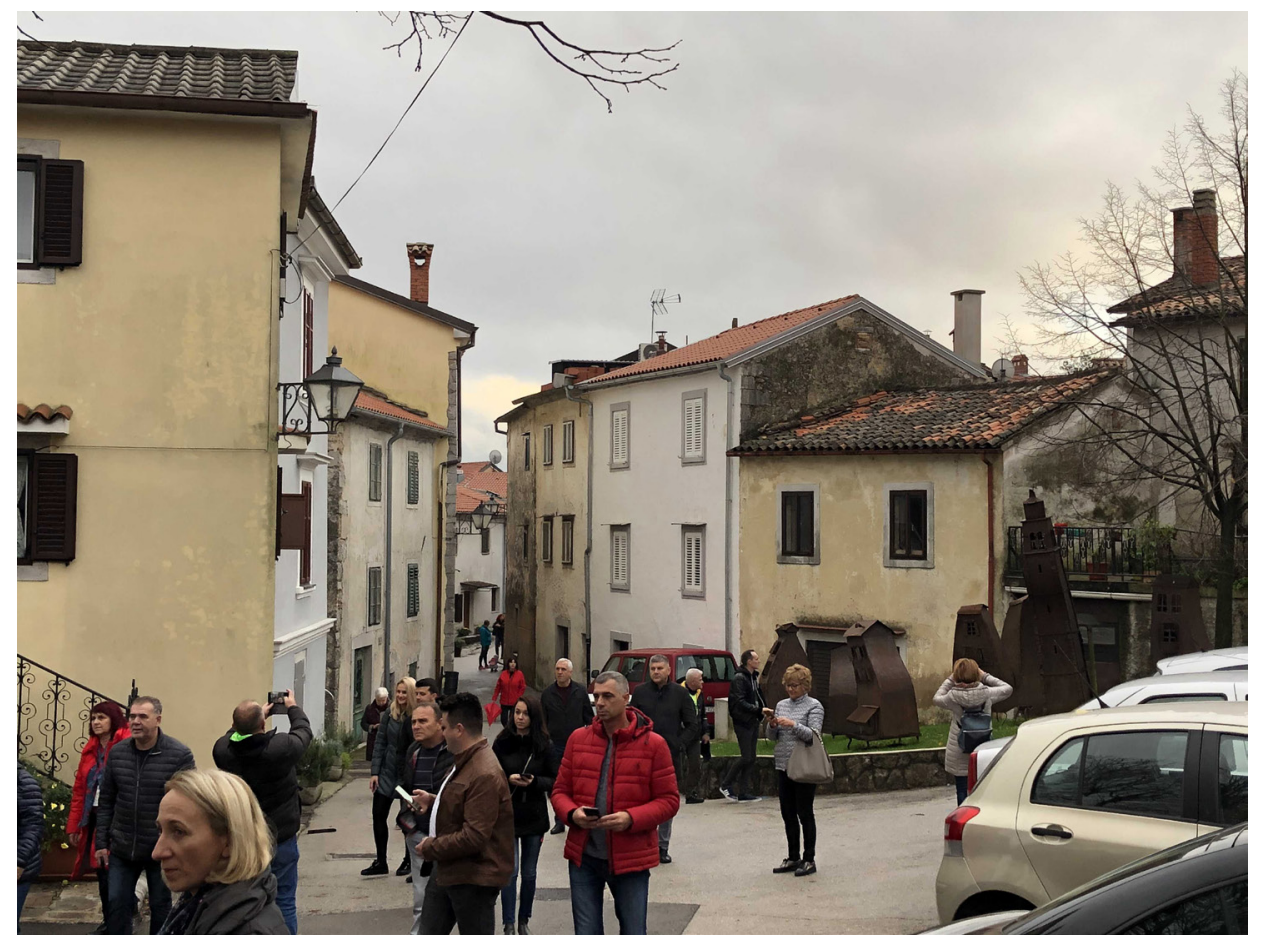

Celoten dogodek je odlično pripravila Hrvaška mreža za podeželje s partnerji, med katerimi je treba posebej izpostaviti Društvo za razvoj slovenskega podeželja (http://www.drustvo-podezelje.si/). Lokalna akcijska skupina med Snežnikom in Nanosom pa je v okviru tematskega terenskega ogleda udeležencem predstavila nekatere 
izvedene projekte. Na konferenci so bile predstavljene tudi slovenske izkušnje pri izvajanju programa LEADER (tako z vidika organov upravljanja - MKGP, z vidika lokalnih akcijskih skupin kot tudi z raziskovalnega vidika).

Program LEADER nagovarja tudi geografe, kako se lahko aktivno vključimo v razvoj podeželja. Na povezavah boste našli informacije o tem, kaj se dogaja na območju posamezne lokalne akcijske skupine in kako deluje Mreža za podeželje (https://www. program-podezelja.si/sl/zelite-sodelovati/mreza-za-podezelje).

Irma Potočnik Slavič

\section{IZZIVI IN PRILOŽNOSTI MULTIFUNKCIJSKEGA UPRAVLJANJA TRAVIŠČ}

\section{Mednarodna konferenca; Ptuj, 15.-17. 5. 2019}

Od srede, 15. 5. 2019, do petka, 17. 5. 2019, se je na Ptuju odvijala mednarodna konferenca Izzivi in priložnosti multifunkcijskega upravljanja travišč, ki je bila organizirana v okviru projekta LIFE Ohranjanje in upravljanje suhih travišč v Vzhodni Sloveniji in ga vodi Zavod RS za varstvo narave.

Projekt naslavlja pomen ohranjanja in dolgoročnega upravljanja vrstno bogatih suhih travišč, ki so eden najhitreje izginjajočih življenjskih prostorov. Namenjen je izboljšanju stanja in zagotavljanju dolgoročnega upravljanja suhih travišč ter nanje vezanih rastlinskih in živalskih vrst na štirih izbranih projektnih podobmočjih: Haloze, Pohorje, Kum in Gorjanci. Vsa štiri območja spadajo v območja Natura 2000 in se soočajo $z$ dvojnimi izzivi: na eni strani z zaraščanjem in opuščanjem kmetijske rabe, na drugi strani pa s preveč intenzivno kmetijsko rabo. Cilj projekta je izboljšanje stanja dveh Natura 2000 prioritetnih habitatnih tipov travišč v neugodnem stanju, in sicer polnaravnih suhih travišč in grmiščnih faz na karbonatnih tleh, ki so pomembna rastišča kukavičevk, ter vrstno bogatih travišč s prevladujočim navadnim volkom na silikatnih tleh.

V petletnem projektu (2016-2020) z manjšo raziskavo Analiza socialno-ekonomskih vplivov projektnih aktivnosti na lokalno gospodarstvo in prebivalstvo sodelujemo tudi člani Oddelka za geografijo: Katja Vintar Mally, Nejc Bobovnik, Simon Kušar in Barbara Lampič, v prvi fazi pa tudi Tanja Koželj. V prvi fazi študije je bil najprej izdelan nabor kazalcev za analizo socialno-ekonomskih vplivov projektnih aktivnosti, nato pa sta sledila izračun in interpretacija kazalcev začetnega stanja. V nabor kazalcev je vključenih skupno 21 kazalcev (devet pretežno demografskega in socialnega značaja ter dvanajst pretežno ekonomskih kazalcev), ki se glede na tip hierarhično 
delijo na temeljne in dopolnilne kazalce. Po zaključeni analizi smo lahko ugotovili, da so med štirimi projektnimi območji mnoge skupne poteze, a tudi bistvene razlike. V drugi fazi študije bo preučitev ponovljena za stanje ob koncu projekta (leta 2020), kar bo omogočilo tudi primerjavo začetnega in končnega stanja ter vrednotenje učinkov projektnih aktivnosti.

Nejc Bobovnik, Barbara Lampič in Katja Vintar Mally smo se tudi udeležili konference, na kateri smo bili, zaradi drugih službenih obveznosti, prisotni samo drugi dan. Prvi dan konference je sicer bil namenjen ekskurziji na območja, bogata $z$ orhidejami v Halozah. Pri tem ne mislimo orhidej, ki jih najdemo v trgovinah, temveč "divje" orhideje (tudi kukavice ali murke), ki so združene v družino kukavičevk. Drugi dan so sledile tri sekcije konferenčnih predavanj, tretji dan pa še četrta sekcija ter zaključek konference $\mathrm{z}$ možnostjo ogleda 30. razstave Dobrote slovenskih kmetij. V četrtek smo torej bili priča trem sekcijam konference - uvodnim nagovorom so sledile izkušnje kolegov iz tujine (Irska, Romunija, Češka in Hrvaška), nato pa še različni domači primeri.

Z uvodnimi nagovori so nas pozdravili podžupan Mestne občine Ptuj Andrej Lazar, direktor Zavoda RS za varstvo narave mag. Teo Hrvoje Oršanič, mag. Marjeta Bizjak iz Sektorja za trajnostno kmetijstvo Ministrstva za kmetijstvo, gozdarstvo in prehrano ter dr. Marko Maver, državni sekretar za področje okolja na Ministrstvu za okolje in prostor.

Sledilo je uvodno predavanje dr. Brendana Dunforda, ki je predstavil kmetovanje kot način ohranjanja območja Burren na Irskem. Predvsem je izpostavil prehod od nekajletnega projekta $\mathrm{k}$ dolgoročnemu upravljanju območja, ki hkrati ohranja kmetovanje in skrbi za izboljšanje stanja na tamkajšnjih traviščih. Ključno sporočilo te irske izkušnje je, da so težave identificirali skupaj s kmeti in oblikovali ukrepe, ki so bili sprejemljivi za obe strani in zajemajo tako finančno, tehnično kot tudi socialno podporo vključenim kmetom. Zaradi dobrih rezultatov projekta so $\mathrm{k}$ nadaljnjemu sodelovanju uspeli prepričati irsko vlado in nadaljevali po zastavljeni poti $\mathrm{v}$ obliki programa The Burren Programme. Ključno je, da so v ospredju kmetje, ki imajo popolno svobodo glede sodelovanja, hkrati pa jim ni treba skrbeti za birokracijo. Drug pomemben vidik je dejstvo, da gre za program, temelječ na rezultatih, kar pomeni, da so kmetje (finančno) nagrajeni za stanje na svojih traviščih in opravljene aktivnosti. Vrednotenje stanja travišč opravljajo nadzorniki enkrat letno s pomočjo enostavnega obrazca. Kmetje se na rezultate lahko pritožijo, vendar so pritožbe zelo redke, saj lahko kmetje iz leta $\mathrm{v}$ leto rezultate izboljšajo in so za tovrstna konkretna prizadevanja deležni še dodatne finančne spodbude. Uspešnost programa je vzpodbudila 23 podobnih programov po celotni Irski.

Popa Razvan Daniel nam je predstavil načine, kako se lotevajo identifikacije, spremljanja stanja, ohranjanja travišč in kompenzacijskih plačil kmetom na območju Osrednje Transilvanije v Romuniji. Eden njihovih večjih problemov je bila intenzifikacija paše, zato je med glavnimi ukrepi zmanjševanje števila živine. Karel Fajmon je 
predstavil načine obnavljanja travišč v Belih Karpatih na Češkem, pri čemer je pokazal zanimive pristope $\mathrm{k}$ zbiranju semen na traviščih in prenosu te semenske mešanice na druga območja. Za zaključek tega vsebinskega sklopa smo se prestavili v neposredno soseščino, na zavarovano območje parka Žumberak - Samoborsko gorje na sosednjem Hrvaškem. Katarina Husnjak Malovec nam je predstavila izzive, s katerimi se srečujejo pri ohranjanju biotske raznovrstnosti. Izpostavljena je bila predvsem zelo slaba demografska slika območja ter posledično pomanjkanje delovne moči in tudi tradicionalnega znanja pri košnji travišč.

Ena izmed številnih predstavitev na konferenci (arhiv projekta LIFE TO GRASSLANDS (LIFE 14 NAT/SI/000005)).

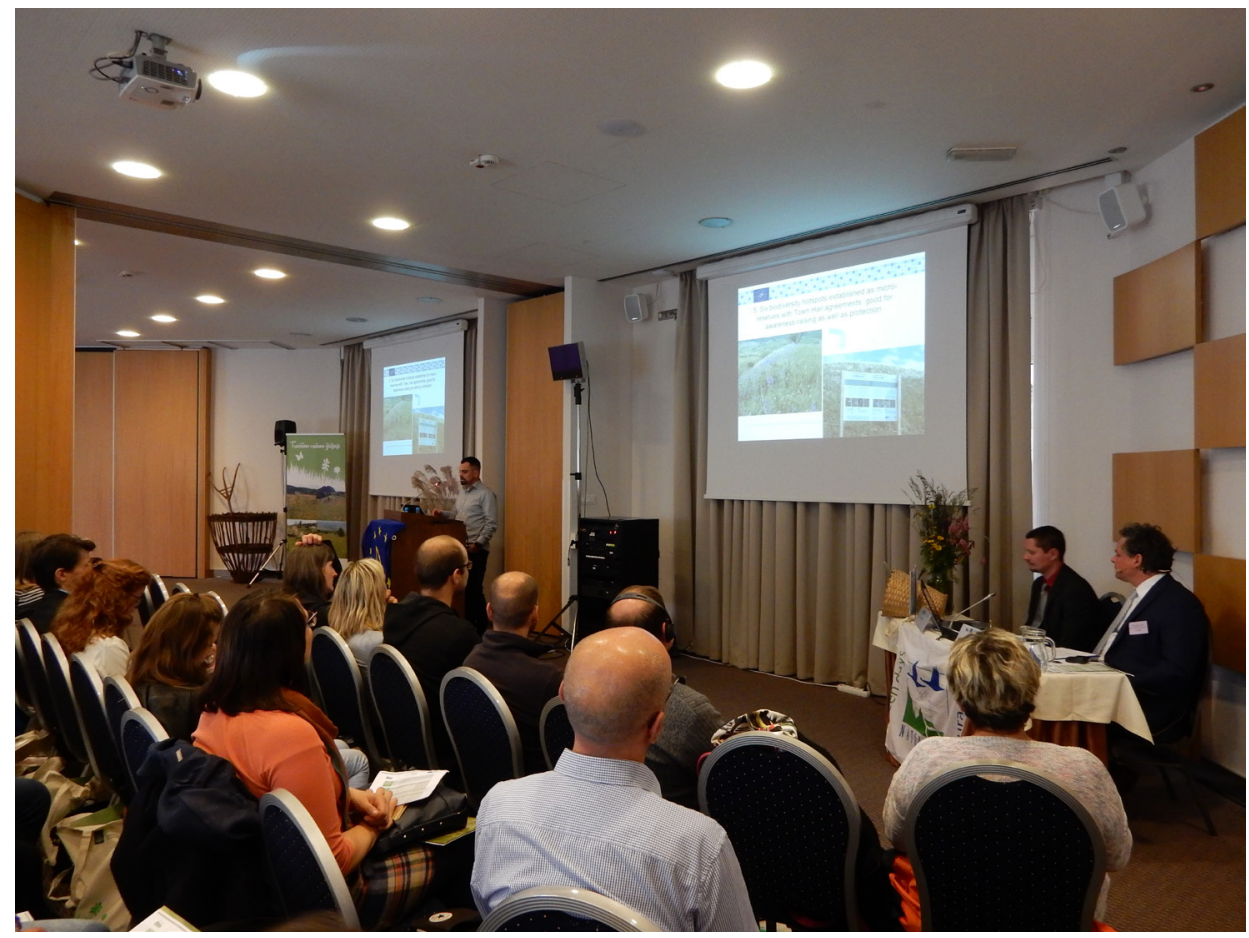

Po odmoru je sledila tretja sekcija konference, kjer so nam predavatelji predstavili nekatere primere z območja Slovenije. Prva je bila dr. Nika Debeljak, ki je vodja projekta Ohranjanje in upravljanje suhih travišč v Vzhodni Sloveniji. Projekt, ki se končuje v letu 2020, vključuje 163 kmetij s 359 lastniki in obsega 570 hektarjev upravljanih zemljišč. Na teh območjih izvajajo kar nekaj ukrepov, ki pomagajo izpolnjevati cilje projekta. Med ukrepi so odstranjevanje zarasti oziroma čiščenje zaraščenih zemljišč, postavitev ograj za vzpodbujanje paše, nabava strojne opreme za košnjo 
in sadik za vzpostavitev ekstenzivnih visokodebelnih sadovnjakov, izobraževanje in mreženje lastnikov ipd. V nadaljevanju bodo za 49 kmetij pripravili tudi podrobnejši načrt upravljanja, s čimer bodo še nadgradili že pripravljene personalizirane priročnike za kmetije in skušali zagotoviti dolgoročnejše učinke projekta. Mojca Kunst iz Kozjanskega regijskega parka je predstavila podoben projekt, ki je potekal na območju Vetrnika in Oslice v bližini Kozja, Gregor Domanjko pa izkušnje Krajinskega parka Goričko, ki upravlja 38 ha zemljišč z namenom ohranjanja habitatnih tipov za pomembne rastlinske in živalske vrste. Dan smo zaključili s predavanjem Janka Verbiča o dolgoročnih učinkih gnojenja kraškega travnika na rastlinsko pestrost, količino in krmno vrednost pridelane krme. Predavanje je opozorilo na pomen premišljene rabe gnojil, pri čemer raziskovalci v dolgoletnih poskusih ugotavljajo, da je vrstna pestrost največja na negnojenih kraških travnikih, najmanjša pa na travniških površinah, intenzivno gnojenih $z$ dušikom. Tovrstna in druga na konferenci predstavljena spoznanja iz prakse bodo lahko številni udeleženci konference iz raznolikih strok koristno uporabili pri svojem nadaljnjem delu na področju varstva narave in okolja ter še posebej upravljanja travišč.

\section{Nejc Bobovnik, Barbara Lampič in Katja Vintar Mally}

\section{MESEC PROSTORA 2019}

\section{Novi pristopniki v kmetijstvo}

Mesec prostora je pobuda Ministrstva za okolje in prostor, da različni deležniki čas med Svetovnim dnevom habitata (7. oktober) in Svetovnim dnevom mest (31. oktober) posvetijo promociji trajnostnega prostorskega razvoja. Pobudi se je že prvo leto (2014) pridružil tudi Oddelek za geografijo. Letošnji dogodek je potekal v sredo, 23. oktobra, posvečen je bil problematiki dostopa do finančnih virov novih pristopnikov v kmetijstvo.

Prvi del dogodka je bil namenjen uvodnemu pozdravu vodje katedre za regionalno analizo in planiranje na Oddelku za geografijo, dr. Simona Kušarja. Sledil je uvod $\mathrm{v}$ tematiko novih pristopnikov v kmetijstvo in predstavitev projekta NEWBIE, ki ga je pripravila dr. Irma Potočnik Slavič. Udeleženci so se tako seznanili z ovirami, s katerimi se srečujejo novi pristopniki, in se do njih tudi sami opredelili s pomočjo spletne ankete, ki so jo izpolnili na svojih mobilnih telefonih. Kot ključne ovire se izkazujejo dostopanje do kmetijskih zemljišč, dostopanje do finančnih sredstev in dostopanje do trga. Seznanitvi s tematiko sta sledili predstavitvi mladih kmetov, ki sta predstavila svojo zgodbo o začetkih kmetovanja. Prvi je bil Domen Virant s Kmetije Pr` Ropet, ki 
je leta 2015 prevzel opuščeno kmetijo. Sledil pa je Matevž Gartner s Turistične kmetije in sirarstva Gartner, ki je leta 2018 prevzel manjšo kmetijo. Čeprav iz različnih okolij in izhodiščc, sta njuni zgodbi zelo podobni. Sorodne pa so tudi določene ovire, $s$ katerimi se srečujeta kot mlada kmeta, kar še posebej velja za dostop do finančnih sredstev. Pomembna skupna točka obeh je tudi zagnan pristop in nove ideje, s katerimi se lotevata kmetijstva.

Po odmoru nam je gost $z$ Univerze uporabnih znanosti iz Južne Vestfalije, dr. Bernd Poelling, predstavil, na kakšne načine do financ dostopajo novi pristopniki v Nemčiji. Ugotovili smo, da so nekatere (prostorske, finančne in druge) razmere v Nemčiji precej drugačne od slovenskih, vendar so ovire, s katerimi se soočajo mladi kmetje, precej podobne. Podobne so tudi nekatere rešitve, spet druge pa so bolj inovativne in so v Sloveniji prisotne le v manjši meri. To bi denimo veljalo za kampanje za množično financiranje in koncepte delničarstva. Marija Brodnik Lodewijk z Ministrstva za kmetijstvo, gozdarstvo in prehrano nam je $\mathrm{v}$ nadaljevanju predstavila trenutne razpoložljive (državne) pomoči za mlade kmete v Sloveniji ter postopke, ki jih je pri tem treba izpolniti. Nadaljevali smo s spoznavanjem zadružništva kot učinkovite oblike poslovnega organiziranja, ki ga je predstavil Peter Vrisk, predsednik Zadružne zveze Slovenije. Zadružništvo ima v Sloveniji bogato tradicijo in je tudi pomemben razvojni dejavnik slovenskega kmetijstva in podeželja. Kljub temu pa se zdi, da bi povezovanje lahko bilo še bolj intenzivno. Kot premalo izkoriščene se kažejo tudi povezave med kmeti in Slovenskim regionalnim razvojnim skladom, ki bi kmetom lahko pomagal prebroditi finančno vrzel med odobritvijo nepovratnih spodbud in prejemom subvencije. Ta del nam je predstavil v. d. direktorja sklada Velislav Žvipelj.

V dopoldanskem delu smo tako najprej spoznali ovire, s katerimi se soočajo mladi pristopniki, nato pa dobili vpogled tudi v nekatere možne načine odpravljanja teh ovir. Kot zelo pomembno se kaže predvsem povezovanje deležnikov in boljše informiranje, na kar cilja tudi projekt NEWBIE, pri katerem sodeluje naš Oddelek za geografijo.

Popoldanski del je bil namenjen delavnici s študenti geografije, ki sta jo moderirala Sara Uhan in Nejc Bobovnik. Na začetku so študentje odgovarjali na tri vprašanja:

- kako mladi doživljajo prisotnost mladih in novih kmetov;

- za kaj bi oni kot mladi kmetje porabili finančna sredstva;

- kako si zamišljajo delovanje podpornega okolja, ki bi novim pristopnikom in mladim na podeželju nudilo finančne storitve?

Odgovori študentov na vprašanja so bili zelo tehtni in so zajeli širok spekter različnih vsebin, kar bo zagotovo prišlo prav tudi sodelavcem pri projektu. V nadaljevanju so študentje preko igre vlog po skupinah predstavili tri zgodbe različnih kmetij. Čeprav so se kmetije med seboj razlikovale po proizvodni usmerjenosti (mešana, živinorejska in vinogradniška) in generacijski strukturi (mladi prevzemnik, mladi kmet, ki že dela na kmetiji, a je še ni prevzel in starejši kmet), je bila vsem skupna usmerjenost na lokalni trg in zavezanost $\mathrm{k}$ bolj ekološki pridelavi. Podobno razmišljanje študentov se je pokazalo tudi v razpravi, ki je sledila predstavitvam in pri kateri sta 
sodelovala tudi tuja gosta oddelka, dr. Tessa Avermaete in dr. Bernd Poelling. Letošnji dogodek je na Oddelek za geografijo privabil več kot 70 udeležencev: študentov magistrskega študija geografije, študentov in profesorjev z Biotehniške fakultete, geografov iz prakse ter pomembnih deležnikov, ki sestavljajo podporno okolje novih pristopnikov v kmetijstvo. Za pomoč pri sodelovanju se zahvaljujemo vsem sodelujočim, še posebej pa študentom smeri Regionalno planiranje in urbano-ruralne študije.

Zbornik povzetkov je dostopen na spletni strani Oddelka za geografijo: http://geo. ff.uni-lj.si/publikacije/druge_publikacije. Če pa vas zanimajo tematike novih pristopnikov, ste lepo povabljeni, da se vključite v Mrežo NEWBIE (http://www.newbie-academy.eu/membership-si/), si ogledate nekaj osebnih zgodb ali se celo prijavite na natečaj za »Najbolj inovativnega novega pristopnika v letu 2019«.

\section{Nejc Bobovnik}

Udeleženci so se s pomočjo mobilnih telefonov opredelili do ovir, s katerimi se soočajo novi pristopniki (foto: N. Bobovnik).

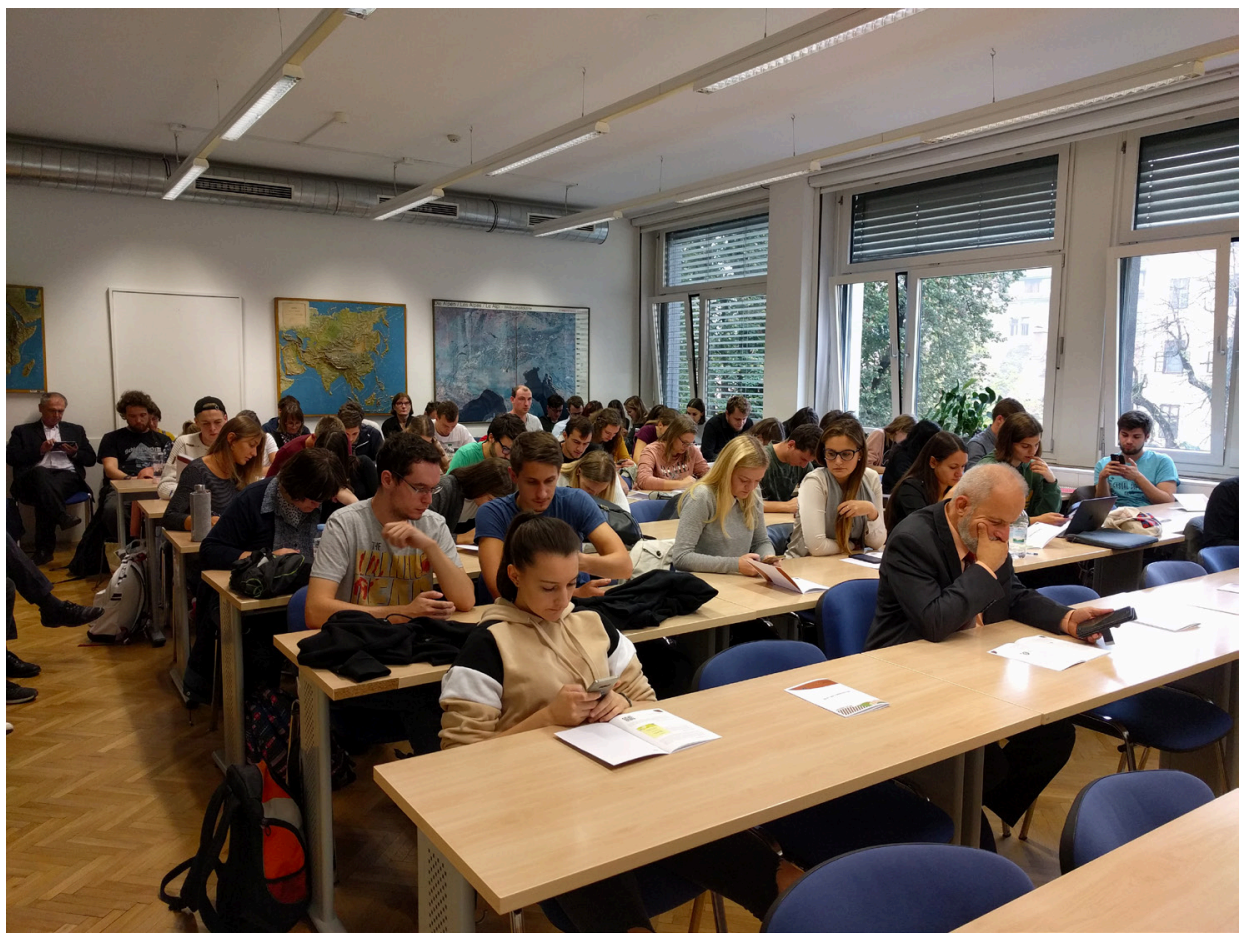


$\checkmark$ drugem delu se nam je pridružilo več predstavnikov podpornega okolja (foto: $N$. Bobovnik).

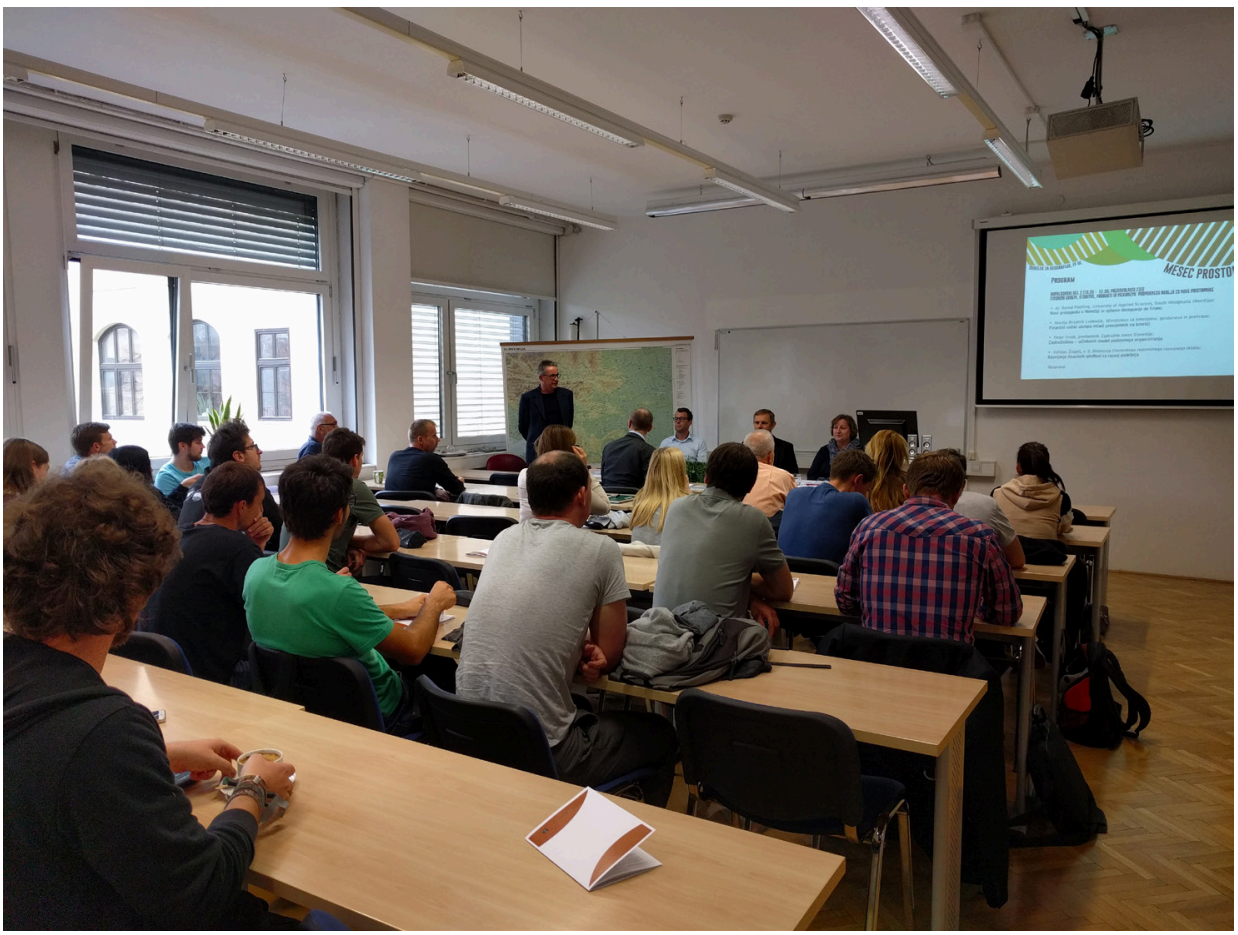

\section{SLOVENSKI PODEŽELSKI PARLAMENT: DELAVNICA MLADI IN NOVI KMETJE TER PODELITEV »NAGRADE NEWBIE 2018«}

5. Slovenski podeželski parlament, ki je zasedal 8. in 9. 10. $2019 \mathrm{v}$ Halozah, nadaljuje bogato in pomembno tradicijo vzpostavljanja participativne demokracije v praksi. Pri organizaciji dogodka sodelujejo Ministrstvo za kmetijstvo, gozdarstvo in prehrano, Društvo za razvoj slovenskega podeželja in partnerji Mreže za podeželje. Letošnjega dogodka se je udeležilo več kot 350 udeležencev iz Slovenije in drugih evropskih držav. Glavna tema razprav je bila Skupna kmetijska politika po letu 2020, ki pomembno sooblikuje slovensko podeželje. Prvi dan je bil namenjen tematskim delavnicam, ki so se izvajale na devetih različnih lokacijah v Halozah, na katerih so domačini lahko predstavili tudi konkretne rezultate številnih prizadevanj na področju 
razvoja podeželja. Večerni del je bil namenjen bogatemu kulturnemu programu in podelitvi dveh nagrad (razglasitev slovenskega predstavnika za Evropsko nagrado za najuspešnejšo podeželsko skupnost za leto 2020 in podelitev nagrade za najbolj inovativnega novega pristopnika v kmetijstvo). Drugi dan je bil namenjen celoviti predstavitvi ugotovitev tematskih delavnic ter širši razpravi o razvojnih predlogih. Več o dogodku si lahko preberete na: http://drustvo-podezelje.si/podezelski-parlament/ slovenski-podezelski-parlament/5-spp.

Oddelek za geografijo Filozofske fakultete Univerze v Ljubljani je na 5. Slovenskem podeželskem parlamentu sodeloval $\mathrm{z}$ delavnico Mladi in novi kmetje ter s slovesno podelitvijo Nagrade NEWBIE 2018 za uspešnega in inovativnega novega pristopnika v Sloveniji. Irma Potočnik Slavič in Sara Uhan sta vodili delavnico Mladi in novi kmetje, ki se je vsebinsko navezovala na projekt NEWBIE (New Entrant netWork: Business models for Innovation, entrepreneurship and resilience in European agriculture; projekt Horizon 2020, povezava: www.newbie-academy.eu). Za ohranjanje vitalnosti, prožnosti in konkurenčnosti evropskega podeželja je izjemnega pomena delovanje kmetijskega sektorja. Le-ta se sooča s premajhnim dotokom mladih in inovativnih kmetijskih praks, zato v pripravah na Skupno kmetijsko politiko po letu 2020 različne evropske ustanove, povezane $\mathrm{z}$ razvojem kmetijskega sektorja (npr. CEJA, DG AGRI in Kompetenčni center za razvojne napovedi pod sloganom »Kmetje prihodnosti leta 2040 «ipd.), skušajo pridobiti različne pobude in priporočila, predvsem pa informacije od neposredno udeleženih, kako oblikovati prihodnje stimulativno podporno okolje za pomladitev in razvoj kmetijskega sektorja.

V delavnici nas je zanimalo, $s$ kakšnimi ovirami se soočajo tako mladi kot tudi novi kmetje, ki vstopajo v kmetijski sektor (npr. ovire pri dostopanju do kmetijskih zemljišč, kapitala, znanja, tržišča, delovne sile itd.); kakšne rešitve bi tako mladi kot tudi novi kmetje potrebovali, ko vstopajo v kmetijski sektor in pri izvedbi poslovnega modela; kako se mladi in novi kmetje vključujejo $\mathrm{v}$ življenje na podeželju in kako prebivalci podeželja v vsakodnevnem življenju doživljajo prisotnost mladih in novih kmetov. Udeleženci delavnice so kot glavne ovire prepoznali nezadosten prenos kmetij na mlajše generacije (predvsem zaradi nezagotovljene varnosti za starejše kmete, ki kmetijo predajajo), dostop do trga, finančnih sredstev, informacij, znanja in neustrezno zemljiško politiko. Predlagali so dve rešitvi: 1) spodbujanje povezovanja kmetov preko ustanovitev združenj kmetov oziroma organizacij, in sicer s sofinanciranjem zagonskih administrativnih in promocijskih stroškov v času petih let; 2) spodbujanje prenosa družinskih kmetij $\mathrm{z}$ »rento « za starejše kmete ali sistemom mentorstva.

$\mathrm{V}$ večernem programu smo podelili Nagrado NEWBIE, namenjeno uspešnim in inovativnim novim pristopnikom $\mathrm{v}$ kmetijstvu $\mathrm{v}$ devetih partnerskih državah $\mathrm{v}$ Evropi. Z nagrado želimo prepoznati in predstaviti tiste kmete/kmetice, ki so razvili oziroma razvijajo zanimive in uspešne vstopne in poslovne modele. V letu 2018 je prejemnica Nagrade NEWBIE „Biodinamična kmetija Turinek - Zlate misli«, ki jo je družini Turinek podelila Silvia Michelini, predstavnica Direktorata za kmetijstvo 
Evropske komisije. Desetčlanska strokovna komisija je o nagrajeni kmetiji zapisala: "Gre za kmetijo, ki predstavlja zaokroženo gospodarsko enoto, od pridelave do predelave in trženja. Prav slednje izvaja na zelo izviren, inovativen način, ki vključuje tudi skupinski pristop. Spekter načinov prenosa znanj je zelo širok, saj vključuje tako prenos praks kot tudi izobraževanja, izvedbo delavnic, mednarodne konference in izmenjavo prostovoljcev. Načrti za prihodnost vključujejo trajnostni razvoj, so optimistični, predvsem pa usmerjeni v prava in najbolj pereča področja. Želijo si okrepiti prožnost tako na pridelovalnem kot tudi prodajnem področju."

Tematske delavnice so potekale na različnih lokacijah v Halozah (foto: S. Uhan).

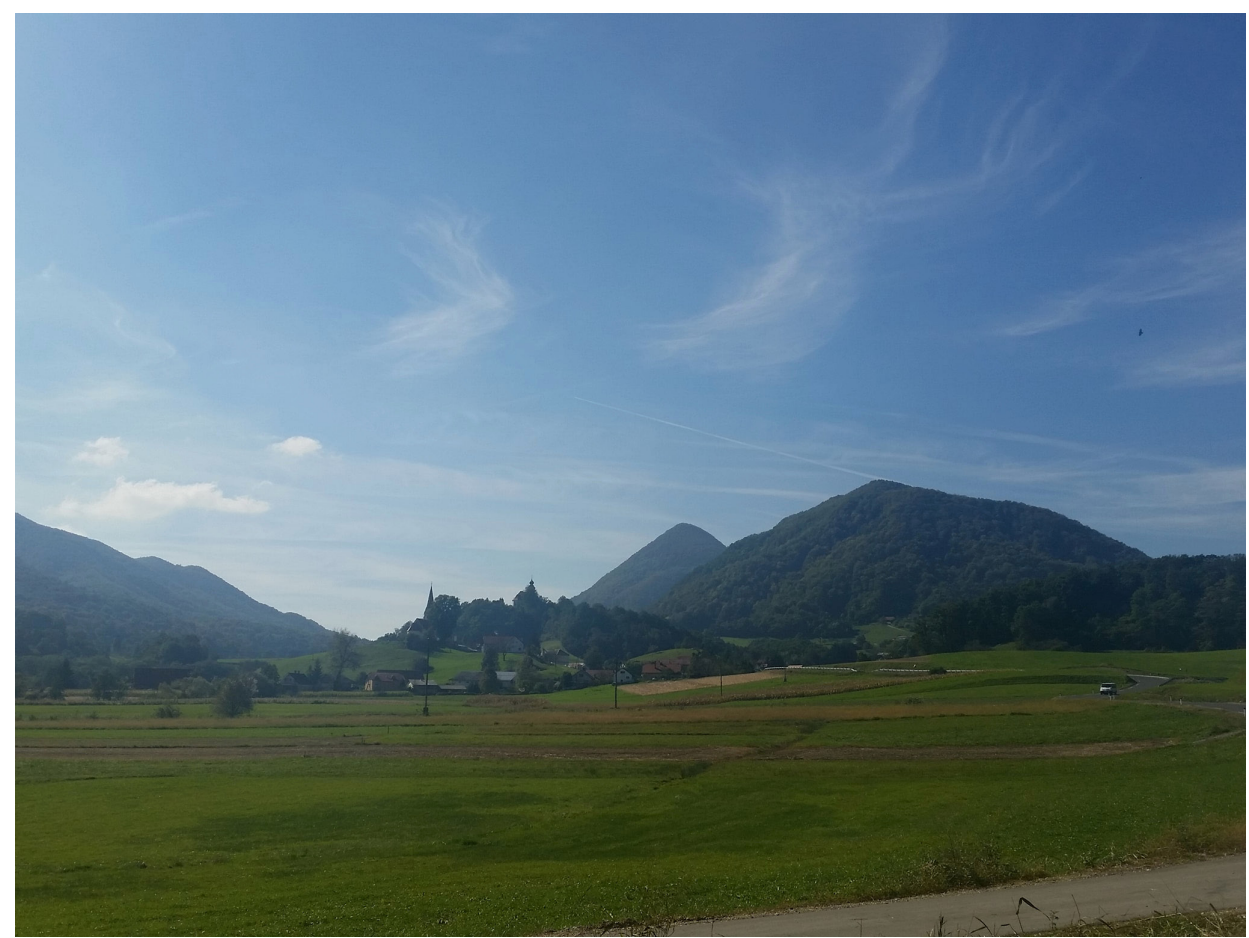

Biodinamični kmetiji Turinek je omogočeno koriščenje Nagrade NEWBIE $\mathrm{v}$ najvišji skupni vrednosti do 1500 EUR bruto v skladu s potrebami kmetije, in sicer za: 1) snemanje predstavitvenega videa (dostopen na povezavi: https://youtu. be/_mtms2Qlz8Q) in za 2) financiranje izobraževanja/usposabljanja - družina se je odločila za obisk enotedenske delavnice januarja 2020 v švicarskem Dornachu.

Nagrajeni kmetiji iskreno čestitamo, obenem pa izrekamo naše priznanje tudi vsem novim pristopnikom, ki so izkazali veliko mero inovativnosti pri poslovnih modelih, iskanju tržnih vrzeli in pozicioniranju kmetij v lokalni skupnosti. Nove pristopnike 
vabimo, da se prijavijo na razpis za Nagrado NEWBIE v letu 2019. Vse geografe in geografinje (mogoče so med vami tudi novi pristopniki) ter vse druge deležnike podpornega okolja (kmetijska svetovalna služba, različne ustanove na lokalni, regionalni in državni ravni) pa spodbujamo, da spremljate aktivnosti projekta NEWBIE (http:// geo.ff.uni-lj.si/raziskovanje/raziskovalni_projekti/newbie).

\section{Sara Uhan in Irma Potočnik Slavič}

Nagrajena družina Turinek z ministrico, predstavnico DG AGRI, organizatorii podeželskega parlamenta in projektnima sodelavkama (foto: K. Gajšek).

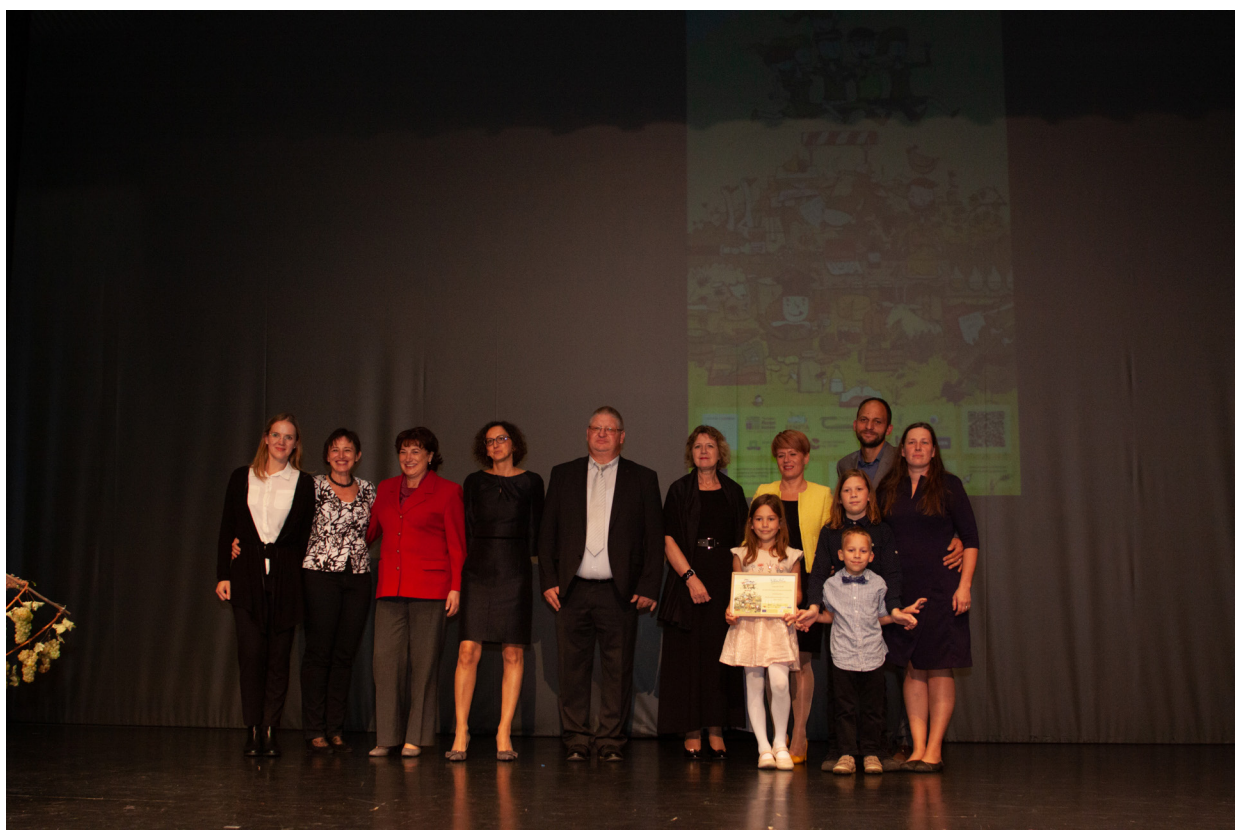




\section{NAGRAJENI REZULTATI GEOGRAFSKEGA PROUČEVANJA (FUNKCIONALNO) DEGRADIRANIH OBMOČIJ V LETU 2019}

Sodelavci Oddelka za geografijo Filozofske fakultete Univerze v Ljubljani že več let raziskujemo problematiko trajnostne rabe prostora, od leta 2015 dalje pa smo se načrtno usmerili v proučevanje različnih možnosti vzpostavitve delujočih trajnostnih pristopov $\mathrm{v}$ prostorskem načrtovanju. Ker se odnosi med različnimi dejavnostmi v prostoru skupaj z družbenimi potrebami hitro spreminjajo, nenehna rast potreb po novih površinah pa je stalnica, posebno pozornost posvečamo obravnavi funkcionalno razvrednotenega prostora. To so nezadostno izkoriščeni ali povsem zapuščeni prostori zaradi opustitve izvajanja dejavnosti, označili pa smo jih kot funkcionalno degradirana območja (FDO). Metodološki pristop pri geografski obravnavi takih območij je zorel že nekaj časa, začetki pa segajo v leto 2010, ko smo v okviru CRP projekta Sonaravna sanacija okoljskih bremen (nosilka projekta dr. Metka Špes) evidentirali 192 degradiranih območij in zasnovali prvo prostorsko bazo. Ta prostorska baza je nekaj let služila kot referenčna evidenca degradiranih območij v Sloveniji (uporabili smo prostorski prikaz v Geopediji). Za nekaj let je raziskovanje na tem področju zamrlo, kasnejše aktivnosti, ki so se pričele izvajati na različnih področjih in bolj sistematično, pa je vodila in usmerjala dr. Barbara Lampič. Temelje metodološkemu pristopu in teoretični zasnovi raziskovanja tega področja smo postavili v okviru študentskega projekta PKP (Pilotna obravnava FDO v gorenjski statistični regiji, 2015) ter CRP projekta Celovita metodologija za popis in analizo degradiranih območij, izvedba pilotnega popisa in vzpostavitev ažurnega registra (2015-2017, Oddelek za geografijo Filozofske fakultete kot vodilni partner in pobudnik projekta). V okviru slednjega smo geografi skupaj s projektnimi partnerji (Fakulteta za gradbeništvo in geodezijo ter Geodetski inštitut Slovenije) vzpostavili prvo državno evidenco funkcionalno degradiranih območij v Sloveniji. Na podlagi raziskovalno-strokovnega dela projektne skupine ter z vključevanjem deležnikov na lokalni (občine), regionalni (regionalne razvojne agencije) in državni ravni (ministrstva) je bil sprva vzpostavljen prostorsko-podatkovni sloj funkcionalno degradiranih območij (FDO) za pilotna območja, v letu 2017 pa izveden še popis FDO v preostalem delu države. Slovenija od leta 2017 tako prvič razpolaga z državno evidenco FDO pa tudi s sistemom za njeno ažuriranje.

Na območju celotne države je bilo leta 2017 popisanih 1.081 FDO v skupni površini 3.423 ha. Za vsa FDO smo pridobili vrsto informacij, od fizičnega stanja na območju, prisotnosti stavb, časa opuščenosti, vrste lastništva do vrste pretekle dejavnosti, različnih oblik degradacije (okoljske, socialne idr.). Posebej velja izpostaviti vlogo geografskega pristopa ter podrobnega pregleda vseh območij na terenu. $\mathrm{Na}$ koncu se je, kljub siceršnjim dvomom o smiselnosti takšnih metod v podatkovno bogatem in z GIS-i prežetem 21. stoletju, terensko delo izkazalo kot ključno ne le 
za pripravo novega prostorskega sloja, ampak tudi za boljše razumevanje dejanskih prostorskih procesov. Z obiskom prav vseh slovenskih občin smo preverili tudi načrte za oživitev FDO oziroma so občinski predstavniki opredelili ključne razvojne ovire za njihovo oživitev.

Državna evidenca FDO je ob upoštevanju načel trajnostnega razvoja pomemben doprinos h kulturi prostora ter se neposredno nanaša na enega od perečih prostorskih problemov v Sloveniji in tudi drugod: neustrezno načrtovanje in neracionalno ravnanje s prostorom. Prostorski sloj je omogočil oblikovanje kazalnika za spremljanje prostorskih procesov v kontekstu trajnostnega in učinkovitega upravljanja naravnih virov (Cilj 9 Strategije razvoja Slovenije 2030). Evidenca FDO je strokovna podlaga za pripravo nove generacije regionalnih razvojnih programov in tudi načrtovanih regionalnih prostorskih planov (Operativni načrt o sodelovanju ministrstev pri pripravi regionalnih razvojnih programov za obdobje 2021-2027). Evidenca je tako prepoznana kot pomemben instrument za strateško načrtovanje prostorskega razvoja $\mathrm{v}$ kontekstu koncepta ničelne pozidave prostora na državni, regionalni in lokalni ravni ter »recikliranje« oziroma ponovno rabo predhodno že uporabljenega, tudi degradiranega prostora. Zasluge imamo tudi pri vzpostavljanju komunikacije s številnimi relevantnimi resorji (MOP, MK, MKGP, MZ, MJU idr.) ter lokalnimi skupnostmi (vsemi slovenskimi občinami).

Pomen vzpostavljene državne evidence funkcionalno degradiranih območij skupaj z našimi znanstvenimi, strokovnimi in komunikacijskimi prizadevanji je prepoznala tudi širša strokovna javnost. Za vse dosežke je bila interdisciplinarna projektna skupina pod vodstvom dr. Barbare Lampič z Oddelka za geografijo Filozofske fakultete Univerze v Ljubljani nagrajena s Priznanjem Maks Fabiani za leto 2019 za posebne dosežke na področju urbanističnega, regionalnega in prostorskega načrtovanja. Nagrado podeljujejo Društvo urbanistov in prostorskih planerjev Slovenije, Ustanova Maks Fabiani in Občina Komen v sodelovanju z Ministrstvom za kulturo ter Ministrstvom za okolje in prostor Republike Slovenije.

Žirija je med drugim zapisala: "Delo predstavlja temeljito inventarizacijo funkcionalno degradiranih območij in korak k sanaciji le-teh. Gre za sistematičen in kompleksen pristop, ki je vključeval veliko deležnikov. Prispeva k razvoju metodologije za vzpostavitev državne evidence funkcionalno degradiranih območij v Sloveniji. Je pomembno v pogledu razvoja in uporabe tehnik daljinskega zaznavanja in terenskega dela, razvrščanja degradiranih območij po njihovi vrsti, velikosti, okoljski in socialni problematiki. Glede na uporabljene podatkovne baze in med projektom izvedene komunikacije prinaša kredibilno sliko stanja in bo lahko uporabno tudi za regionalne in občinske ravni načrtovanja."

Opravljeno strokovno in raziskovalno delo je bilo opaženo tudi v tujini. Dosežek »Vzpostavitev državne evidence funkcionalno degradiranih območij v Sloveniji 2017« je namreč prejel nagrado na mednarodni urbanistični razstavi v Nišu, Srbija (oktober 2019) v organizaciji Zavoda za urbanizem Niš in Mesta Niš. V kategoriji 
Urban and spatial planning - researches, studies and projects smo med 17 kandidaturami prejeli drugo nagrado.

$\checkmark$ letu 2019 nagrada Maks Fabiani ni bila podeliena. Od vseh prispelih nominacii sta bili podeljeni le dve priznanii: priznanje, ki ga je prejela interdisciplinarna projektna skupina pod vodstvom dr. Barbare Lampič iz Oddelka za geografijo FF UL za vzpostavitev državne evidence funkcionalno degradiranih območi, ter študentsko priznanje Maks Fabiani, ki so ga prejeli študentke in študenti Oddelka za krajinsko arhitekturo BF UL za urbanistično rešitev $v$ Sao Paulu, Brazilija, s katero so sodelovali na mednarodnem urbanističnem natečaju.

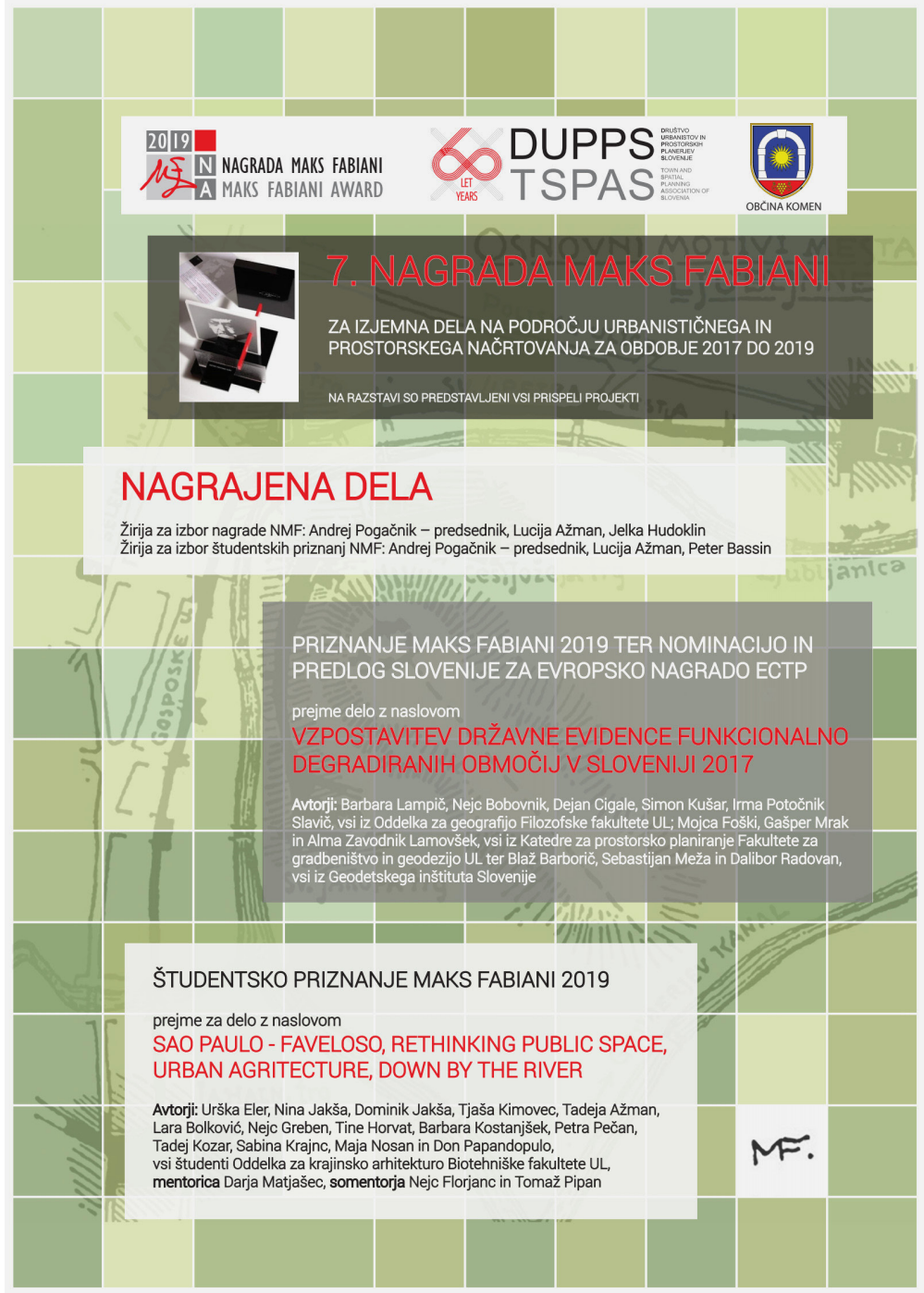


Državna evidenca FDO 2017 je dostopna v Arhivu družboslovnih podatkov. Na pobudo Ministrstva za gospodarski razvoj in tehnologijo smo sredi leta 2019 na oddelku pričeli izvajati prvo ažuriranje baze in v začetku leta 2020 pričakujemo, da bomo že razpolagali z novim prostorsko-podatkovnim slojem ter prvo analizo trendov.

Znanstveni prispevek o FDO v Sloveniji je bil objavljen v Delih 48 (Lampič, Kušar, Zavodnik Lamovšek, 2017), izvajanje CRP projekta pa podrobneje predstavljeno v Delih 50 (Lampič, 2019).

Prejem obeh priznanj v jubilejnem, 100. letu geografije na Univerzi v Ljubljani dokazuje, da je geografski pristop pri obravnavi, analizi in razumevanju prostorskih pojavov in procesov živ, aktualen, zaželen ( $\mathrm{v}$ širši strokovni javnosti, pri odločevalcih) ter nujno potreben; to je prispevek geografske stroke $\mathrm{k}$ bolj trajnostnemu ravnanju $\mathrm{s}$ prostorom v Sloveniji.

\section{Barbara Lampič in Simon Kušar}

Skupinska slika večine nagrajenih avtorjev. Skrajno levo sta dr. Mojca Šašek Divjak, predsednica Društva urbanistov in prostorskih planerjev Slovenije, ter prof. dr. Andrej Pogačnik, predsednik žirije za podelitev Nagrade Maks Fabiani (foto: R. Grobelšek).

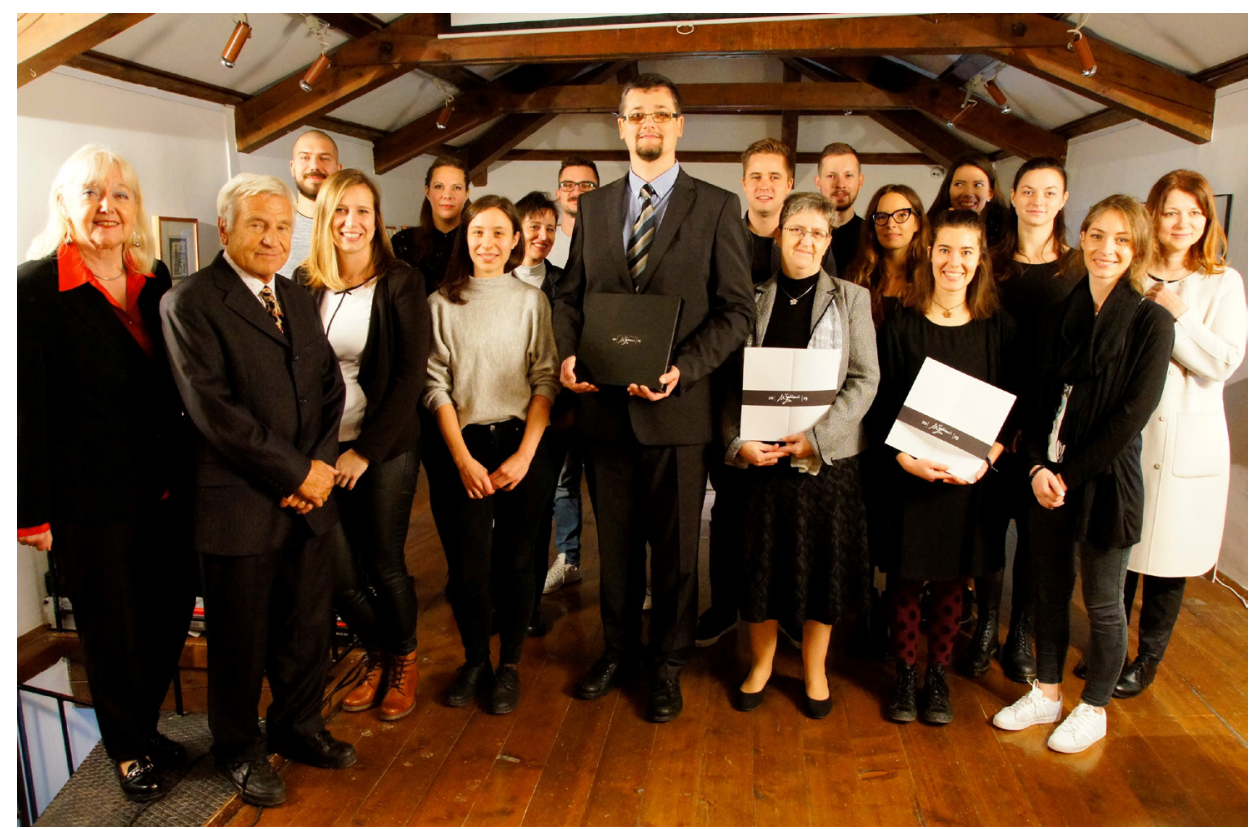

